\title{
SEKURITIZACE HROZBY NEDOSTATKU VODY V ČESKÉ REPUBLICE
}

\section{SECURITIZATION OF THE THREAT OF WATER SCARCITY IN THE CZECH REPUBLIC}

\author{
Petr MARTINOVSKÝ
}

\begin{abstract}
Abstrakt
Hrozba nedostatku vody je vposledních letech vbezpečnostních a strategických studiích často diskutovaným tématem. Chybí však práce zabývající se hodnocením této hrozby pro středoevropský prostor a Českou republiku. Tato studie si klade za cíl vyplnit mezeru a prozkoumat reflexi hrozby nedostatku vody mezi aktéry české bezpečnostní politiky. Metodologickým základem práce je konstruktivistický koncept sekuritizace Kodaňské školy bezpečnostních studií, primární data poskytlo dotazníkové šetření, sekundární a terciární pak analýza relevantních dokumentů. V závěru práce autor mimo jiné částečně odstupuje od konstruktivistického přistupu a na základě zprostředkované zkušenosti a pozorovaných trendi̊ shrnuje základní objektivní rysy hrozby nedostatku vody v České republice.
\end{abstract}

\begin{abstract}
In recent years, a threat of water scarcity has been a frequently discussed topic in security and strategic studies. However, we lack evaluative researches on this threat in the Central European area, especially in the Czech Republic. The aim of this paper is to help with filling the vacancy and to explore the reflection of the threat of water scarcity among Czech security policy actors. Appropriate methodological ground is provided by the constructivist concept of securitization by the Copenhagen School of Security Studies. Primary data have been obtained from questionnaires, secondary and tertiary data subsequently from relevant actors' documents analysis. In the final part of the study, the author partially steps aside from the constructivist view and on the basis of observed trends summarizes the main objective features of the threat itself.
\end{abstract}

\section{Klíčová slova}

Nedostatek vody, sekuritizace, environmentální bezpečnost, Kodaňská škola.

\section{Keywords}

Water scarcity, securitization, environmental security, Copenhagen School.

" Největším skutečným nerostným bohatstvím každého státu není ropa ani zlato, ale půda a voda. “l

(Václav Cílek)

\section{ÚVOD}

Voda je nutnou podmínkou existence živých organismů a základní surovinou pro fungování lidské společnosti. Relativní hojnost vody v našem prostředí nás nenutí přemýšlet o možnosti, že bychom jí někdy měli nedostatek. V mnoha zemích světa je ovšem čistá voda velkým luxusem, který si ne každý může dovolit. Podle statistik OSN nemá více než miliarda lidí př́stup k nezávadné pitné vodě². Existují náznaky, že i Česká republika se může ocitnout v situaci, kdy

\footnotetext{
*E-mail: petr.martinovsky@inbox.com
} 
kvalitní vody - at' již k pití, hygienickým účelům, průmyslové výrobě, zavlažování či jednoduše k uchování životního prostředí - bude na našem území nedostatek.

V tomto textu se pokusím přiblížit vnímání hrozby nedostatku vody v České republice. Toto téma ještě nebylo v českém prostředí zpracováno, což má vliv na podobu, strukturu a zaměření této práce. Půjde tedy o explorační ${ }^{3}$ a popisný výzkum s analytickými prvky.

Nejvhodnějším teoreticko-metodologickým východiskem pro uchopení tématu se jeví přístup Kodaňské školy bezpečnostních studií, nejuceleněji předložený Buzanem, Waeverem a de Wildem v knize Bezpečnost: Nový rámec pro analýzu. Klíčové pojmy analytického rámce jako sekuritizace, referenční objekt, funkcionální aktér, sekuritizační aktér a další nebudu vzhledem k omezenému prostoru zvláště definovat. Pro bližší seznámení s těmito pojmy doporučuji výše uvedenou knihu a příslušná hesla ve sborníku Česká bezpečnostní terminologie ${ }^{4}$.

\section{Diagram 1: Vymezení zkoumaného tématu}

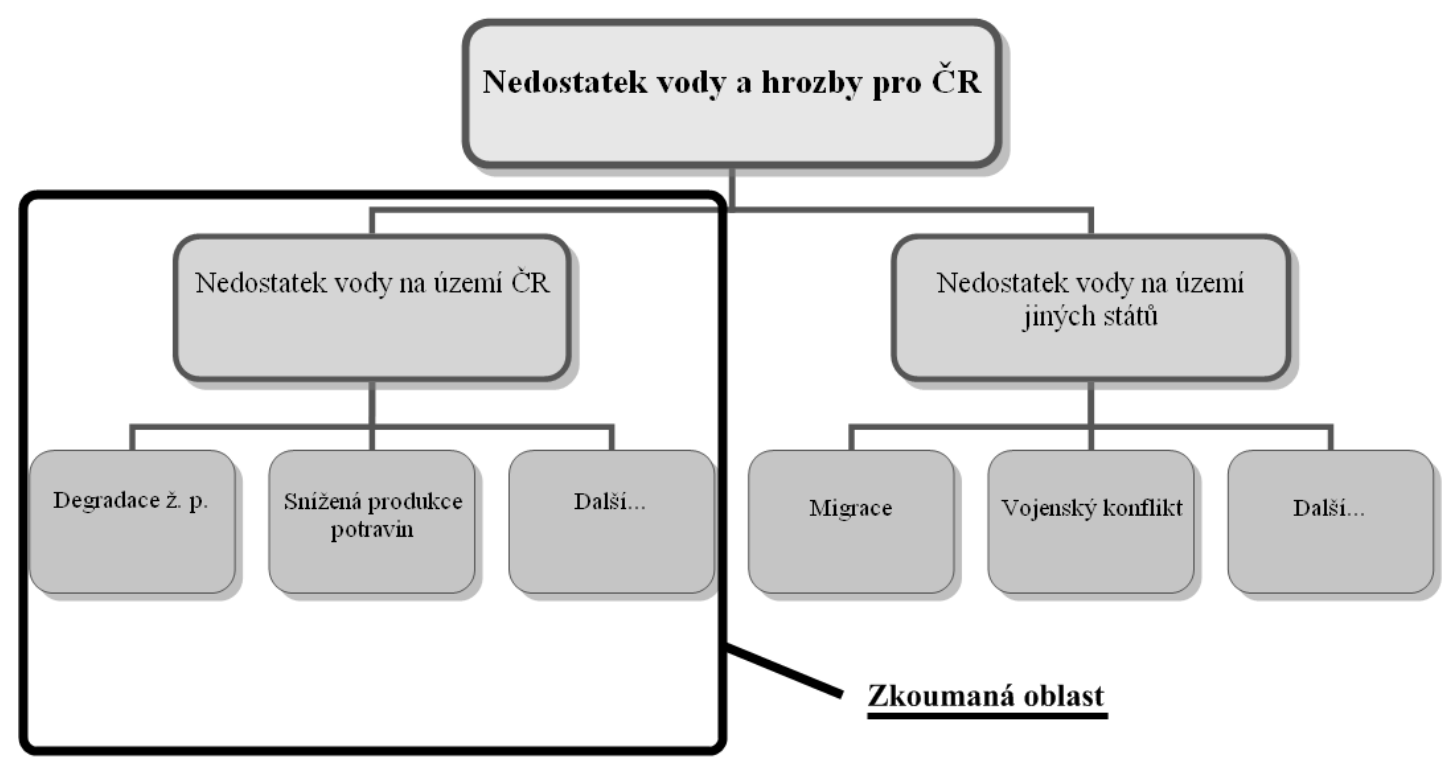

Zdroj: autor.

Omezení výzkumu na Českou republiku bude chápáno jak z hlediska analyzovaných aktérů, tak i z hlediska nedostatku vody na území tohoto útvaru. Cílem této práce není zkoumat př́stup českých aktérů sekuritizačního dění k problematice potencionálního nedostatku vody v jiných zemích (viz diagram 1). I když i toto téma má svůj význam a ačkoli dopad na bezpečnost České republiky může být i závažnějšsí ${ }^{5}$, zkoumání celé šíře tématu a spektra nepřímých hrozeb by narušilo kompaktnost prováděného výzkumu. Omezení zkoumaného problému na území jednoho státního celku by ve většině částí světa bylo obtížné. Česká republika ale zaujímá specifickou geografickou pozici - „na střeše Evropy“6 “ Žádné významné vodní toky na naše území nepřitékají, naše vodní zdroje jsou téměř zcela závislé na doplňování srážkami. Případný nedostatek vody v sousedních zemích tak př́mý dopad na stav vody v našich tocích mít nebude.

Základní výzkumné otázky této práce jsou následující:

- Je hrozba nedostatku vody v České republice sekuritizována?

- Kdo se v sekuritizačním dění angažuje?

○ Kdo téma nastoluje? 
○ Kdo jsou nejvýznamnější sekuritizační aktéři?

- Ve vztahu ke komu je sekuritizace prosazována?

- Jak je sekuritizace této hrozby institucionalizována?

- Jaké jsou význačné rysy hrozby samé, jež ovlivňují sekuritizaci?

Kromě nalezení odpovědi na výše uvedené otázky by tento projekt měl sloužit také k objevení problematických témat $\mathrm{k}$ dalšímu výzkumu. Tuto práci lze také chápat jako test aplikovatelnosti kodaňského analytického rámce na specifickou environmentální hrozbu v konkrétním prostředí.

\section{PouŽitá METOdologie}

Tento výzkum je explorační a popisnou studií s analytickými prvky. Výzkum byl od počátku plánován jako smíšený, kvalitativně-kvantitativní. Výběr sledovaných aktérů byl prováděn technikou sněhové koule ${ }^{7}$, přičemž toto kritérium bylo doplněno samovýběrem - anketou (tj. vrácenými dotazníky). Pro výběr relevantních nevládních neziskových organizací ${ }^{8}$ sloužilo jako základní orientační vodítko členství v organizaci Zelený kruh. Dotazník pro politickou agendu byl odeslán všem poslancům z Výboru pro obranu, Výboru pro bezpečnost a Výboru pro životní prostředí a všem senátorům z Výboru pro zahraniční věci, obranu a bezpečnost a Výboru pro územní rozvoj, veřejnou správu a životní prostředí. Pokud v těchto výborech nezasedají odborníci jednotlivých politických stran na zkoumanou problematiku, byl dotazník odeslán i jim. Z odeslaných 96 dotazníků bylo vráceno 40, tj. $42 \%$.

Závěry tohoto výzkumu jsou založeny jak na primárních datech od aktérů, tak na analýze relevantních dokumentů a literatury.

\section{NASTOLENí TÉMATU NEDOSTATKU VODY}

Počátkem sekuritizačního procesu je nastolení tématu (agenda settings ${ }^{9}$ ). Jde o prvotní impuls, který může vzejít od bezprostředně ohrožených či jako důsledek predikce budoucího stavu.

Dominantními aktéry v procesu nastolování tématu - bezpečnostní hrozby jsou $\mathrm{v}$ environmentálním sektoru vědci a vědecké instituce ${ }^{10}$. Úkolem této kapitoly je prozkoumat vědecké studie, které se zabývají nedostatkem vody v České republice. Bude nás zajímat, kdo se $\mathrm{v}$ agenda settings angažuje, v souvislosti s jakými tématy je nedostatek vody zmiňován i co je považováno za referenční objekt.

Český hydrometeorologický ústav (dále ČHMÚ) se ve sledované oblasti kromě sběru statistických dat zaměřuje především na možný nedostatek vody v důsledku předpovídaných změn klimatu. Odbor klimatologie ČHMÚ ustavil Oddělení klimatické změny, které se věnuje především řešení výzkumných úkolů a jehož internetové stránky (www.chmi.cz/cc) obsahují české překlady nejdůležitějších zahraničních dokumentů s tematikou změn klimatu. Informační brožura o změnách klimatu umístěná na těchto stránkách patří také mezi kvalitní, hodnotově neutrální a vědecky erudované populárně-naučné publikace k tomuto tématu. Pro naši studii má význam především z toho důvodu, že se snaží zachytit i hlavní možné interakce mezi životním prostředím a lidskou společností v případě klimatických změn (viz diagram 2).

ČHMÚ ve spolupráci s Českým národním výborem pro omezování následků katastrof v srpnu roku 2007 vydal krátkou studiii ${ }^{11}$, která rozpracovává poznatky Zelené knihy Evropské komise „Adaptace na klimatické změny v Evropě “12 z června 2007. Třístránková reakce identifikuje hlavní dopady klimatických změn na Českou republiku. Půjde především o:

1. nárůst četnosti a intenzity extrémních povětrnostních jevů (intenzivní srážky s následkem povodní, vlny veder či studených teplot, četnější výskyt bouřek a silného větru),

2. změny v dlouhodobém rozložení teplot a srážek. 


\section{Diagram 2: Model interakcí klimatické změny - společnost}

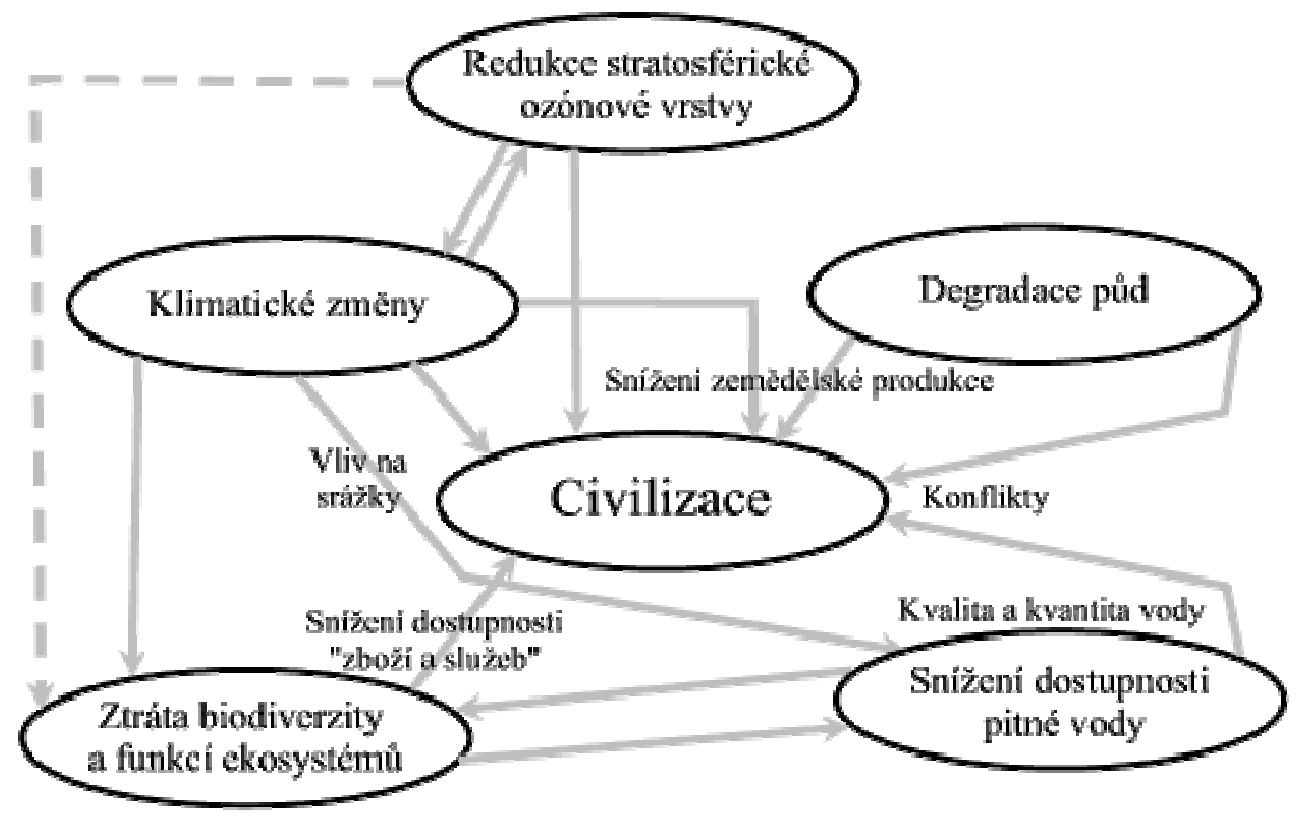

Zdroj: Informační brožura o změně klimatu [online].

ČHMÚ připouští možnost, že změny klimatu nejsou zapříčiněny pouze lidskou činností, což ale nic nemění na tom, že „včasná přijetí opatření mohou přinést zřetelné ekonomické výhody“13. Doporučují se především opatření na místní úrovní. Co je pro náš výzkum důležité, je vymezení čtyř pravděpodobně nejvíce postižených sektorů: hydrologie, vodní hospodářství, zemědělství, lesnictví. Celkově jde o zprávu psanou střízlivým, stručným a srozumitelným jazykem, což svědčí o tom, že je poselstvím širší odborné i laické veřejnosti. Zpráva nastoluje určité téma v prostředí České republiky a přenáší poznatky z evropské úrovně do českého prostředí. Navrhovaná adaptační opatření jsou bezvýhradně zařaditelná do sféry běžné politiky, žádná mimořádná opatření nejsou navrhována.

Změnami klimatu a možnými dopady na životní prostředí a společnost se zabývá také Národní klimatický program. Jde o sdružení 16 právnických osob (výzkumných institucí, kateder na vysokých školách apod.). Právě toto sdružení zaštítilo publikaci série dílčích studií o možných dopadech změny klimatu na hydrologii, zemědělství, lesní hospodářství apod. v České republice. Pro sekuritizaci hrozby nedostatku vody je první důležitou studií práce Josefa Hladného a kol. „Dopady možné změny klimatu na hydrologii a vodní zdroje v České republice“ z roku 1996. I když je toto dílo poměrně zastaralou studií založenou na starších modelech chování klimatu, základní teze se nemění. Důležité je zmínit se o tom, že projekt byl financován vládou USA a tvořil součást širší mezinárodní vědecké studie.

Autoři se snaží predikovat jak ,poptávkovou“ stranu (odběry a spotřeba vody v ČR, trendy vývoje), tak i „nabídkovou“ stranu. Zvýšení teplot v souvislosti se změnami klimatu neznamená jen zvýšení evaporace, ale může vést také $\mathrm{k}$,nižší rozpustnosti kyslíku ve vodě, zrychlení rozkladných procesů s následným prohloubením kyslíkového deficitu a vyššího rozvoje eutrofizačních procesủ nejen v nádržích, ale $i$ v tocích ". ${ }^{14}$ Voda tak bude pravděpodobně ubývat a zároveň se bude snižovat i její kvalita s výraznými dopady na ekosystémy i využitelnost zdrojů společností. Na 
hydrologii by největší dopady mělo především zvyšování teplot a snižování srážek. Souběžné zvyšování teplot a snižování srážek o $5 \%$ by vedlo ke snížení odtoku jednotlivých povodí o $30-50 \%{ }^{15}$. Pokud by navíc srážky nebyly rozloženy relativně rovnoměrně, nastal by ještě větší pokles $^{16}$. Na závěr studie předkládá doporučená adaptační opatř̌ení: ${ }^{17}$

a) postupné snižování spotřeby vody obyvatelstvem,

b) posílení zásobování, především čištěním a využíváním odpadních vod,

c) obchodování s vodou, flexibilní zajištování dodávek vody do míst, kde je akutní nedostatek, „vodní marketing“,

d) spojité hospodaření s podzemními a povrchovými vodami, využívání retenčních vlastností krajiny jako nádrží.

Studie tedy prozatím navrhovala opatření spadající do sféry politizace a nenaznačovala, že by mělo dojít k sekuritizaci problému. Navazující a zpřesňující studie z roku 2002 rozpracovává podrobnější scénáře změny klimatu a jejich dopady na Českou republiku a zároveň koriguje nepřesnosti předchozích modelů, závěry však zůstávají stejné ${ }^{18}$.

Zkoumanému tématu se $\mathrm{z}$ vědeckých institucí věnuje také Výzkumný ústav vodohospodářrský T. G. Masaryka (dále V. Ú. V.). Tato veřejná výzkumná instituce byla zřízena Ministerstvem životního prostředí ( $\mathrm{v}$ návaznosti na dříve existující organizace) též pro vyhodnocování environmentálních rizik v souvislosti s vodními ekosystémy. Velká pozornost je věnována především výzkumu znečištění vod, povodním a dále se, jak napovídá název, instituce zaměřje na praktické vodohospodářské studie monitoringu vodních zdrojů, splavnosti vodních toků, jakosti vod, vodoprávním záležitostem apod. ${ }^{19}$ Podle vyjádření vedoucího Oddělení ekologie a ochrany ekosystémů V. Ú. V. J. Fuksy (které budiž dle jeho přání chápáno jako jeho osobní názor) představuje bezpečnostní problém znečištování vody a její dostupnost v dané lokalitě „Jedna věc je ,suma' vody, druhá věc její jakost pro rüzné účely, třetí věc př́stupnost v konkrétním čase na konkrétním místě s přijatelnými náklady. “20 Z jeho slov jasně plyne, proč v názvu této práce je spojení „,nedostatek vody“, nikoliv ,sucho“. Fuksa zmiňuje nedořešené vypouštění odpadních vod (problémy s financováním a kontrolou) i to, že roste „výroba a spotreba ,chemických látek' - specifických polutantů. Ty nejsou jednoduše kontrolovány současnými systémy “. ${ }^{21} \mathrm{Na}$ látky typu pohlavních hormonů či antibiotik nejsou současné čističky odpadních vod stavěné, takže může snadno docházet ke kontaminaci, o to horší, že se jen obtížně detekuje.

Zamezení znečištování vody je problémem, který byl nastolen již před delší dobou a jak uvidíme v dalších kapitolách, byl politizován, a to tak úspěšně, že dnes okolo 40 \% všech výdajủ na ochranu životního prostředí směřuje na ochranu vod ${ }^{22}$. Více se k problematice znečištování vrátíme také v souvislosti s institucionalizovanou vodohospodářskou strukturou a v souvislosti se snahou některých nevládních organizací o širší politizaci či sekuritizaci tématu.

Chceme-li zkoumat nastolení tématu nedostatku vody, nelze se zaměřit jen výstupy vědeckých institucí. Je nutné zabývat se i míněním jednotlivých vědců, kteří mohou být členy již zkoumaných vědeckých ústavů, ale přesto produkují vlastní studie, případně i vystupují v médiích a prezentují svůj názor. Z logiky věci půjde především o klimatology a hydrogeology.

Jedním z nejčastěji citovaných odborníků je klimatolog Jan Pretel. Jde o bývalého českého zástupce $^{23}$ v Mezivládním panelu pro klimatické změny (Intergovernmental Panel on Climate Change, dále IPCC), vedoucího Oddělení klimatické změny na Odboru klimatologie ČHMÚ. Jan Pretel zdůrazňuje roli adaptačních opatření na klimatické změny a skepticky se staví ke snahám založit boj s oteplováním na snižování emisí, což vyjádřil např́íklad často napadanou větou: „Kjótský protokol nás zachránit žádným způsobem nemůže. “24 Tím jasně vyjádřil svůj názor, že ani okamžité a úplné zastavení emisí skleníkových plynů (technicky neproveditelné) nedokáže zastavit některé změny, které již probíhají.

Pretel chápe adaptační opatření za součást bezpečnostní politiky státu. Jeho osobní názor ${ }^{25}$ tedy doporučuje sekuritizaci, i když konkrétní mimořádná opatření nepředstavuje. Pretel se také 
pokouší překročit hranice svého oboru a snaží se o analýzu rizik vzešlých z globálních klimatických změn. Předpokládá menší míru zranitelnosti u bohatších států, přičemž riziko je dále úměrné:

a) závislosti na přírodních zdrojích,

b) zranitelnosti těchto zdrojů klimatickými změnami,

c) sociálním faktorům, kde explicitně jmenuje životní úroveň, sociální soudružnost a odpovědnost státu ${ }^{26}$.

Tyto Pretelovy poznatky a odhady bohužel dosud nebyly prohloubeny a dále analyzovány. Právě navázání na tyto poznatky v úseku, kde již př́rodní vědy nemohou poskytnout další odpovědi, by mohlo být př́ležitostí pro bezpečnostní studia a další společenskovědní obory. Současný výzkumný projekt „Zpřesnění dosavadních odhadů dopadů klimatické změny v sektorech vodního hospodářství, zemědělství a lesnictví a návrhy adaptačních opatření ${ }^{27 ، ~(z a d a n y ́ ~}$ Ministerstvem životního prostředí na roky 2007-2011) by mohl být krokem kupředu. Řešiteli však budou pravděpodobně pouze přírodovědci a vodohospodáři ${ }^{28}$. Právě bezpečnostní studia (a dále např́íklad ekonomie aj.) by mohla napomoci kvalitnímu vyhodnocení rizik a racionální alokaci prostředků.

Dalším významným geologem a klimatologem, který překračuje hranice svého oboru a pokouší se o predikce možných sociálních dopadů klimatických změn, je Václav Cílek. Cílek je velkým popularizátorem vědy v České republice, často vystupuje v médiích. K tématu nedostatku vody napsal několik spíše esejisticky laděných článkủ ${ }^{29}{ }^{30}$. Poukazuje především na dopady nedostatku vody $\mathrm{v}$ zahraničí na Českou republiku s tím, že tato nebezpečí hrozí dříve než přímý nedostatek vody u nás ${ }^{31}$. V souvislosti se suchem a povodněmi upozorňuje Cílek opakovaně na nebezpečí urbanizace volné půdy ${ }^{32}$, především na trend stavby satelitních městeček. Riziko nedostatku vody to zvyšuje dvojím způsobem. Urbanizované oblasti urychlují odtok vody. Dále je otázkou, zda je možné (a zda to bude možné i v budoucnu) konkrétní lokality zásobovat vodou. Zhodnocení vlivu pokračující urbanizace na hospodaření s vodou v celorepublikovém měřítku by bylo velmi žádoucí.

Extrémním příkladem problémů se zásobováním vodou je Praha, která $98 \%$ pitné vody získává z několik desítek kilometrů vzdálených zdrojů. ${ }^{33}$ Martin Říha, vedoucí SEA $^{34}$ útvaru rozvoje hl. m. Prahy, upozorňuje, že i pokud je takto vzdálené zásobování možné, má svá omezení, především „v dnešní době roste riziko poškození přivaděčů, znehodnocení kvality povrchových vod nekázní zemědělských hospodářù v ochranném pásmu, haváriemi a znečištěním z nich v dopravě, průmyslu, teroristickou akcí ap“. ${ }^{35}$ Ř́ha mluví i o limitech růstu Prahy, resp. do plánů územního rozvoje je prosazován ,,požadavek na stagnaci počtu obyvatel“36.

Zhoršená retenční schopnost krajiny nemusí být jen důsledkem pokračující urbanizace. Jak uvádí např́íklad studie O. Syrovátky, M. Šíra a M. Tesaře, příčin je velké množství, od nevhodných odvodňovacích zásahů přes narovnávání vodních toků a znehodnocování luk ${ }^{37}$ až po snahy o intenzifikaci zemědělské produkce (např. dřívější rozorávání mezí, ale i vápnění a hnojení) ${ }^{38}$. Zdánlivě paradoxní je, že spíše než s hrozbou nedostatku vody je problém retenčních schopností krajiny u nás diskutován v souvislosti s hrozbu jednorázového nadbytku vody povodní. Paradox je to ale opravdu jen zdánlivý, nebot' ztráta schopnosti krajiny zadržovat vodu se projevuje extrémnějšími stavy, než je běžné, a tyto výchylky jsou možné na obě strany standardní hydrologické bilance. Většina vědeckých studií zaměřených na retenční schopnosti krajiny zmiňuje vliv retence jak na průběh povodní, tak i sucha ${ }^{39}$.

Problematika retence krajiny je součástí širšího záměru revitalizace říčních systémů. Jde o snahu dosáhnout stability vodního režimu na dílčích územích. Ztráta retenčních schopností krajiny je chápána jako závažný a vysoce aktuální problém. Především staré ekologické zátěže a dřívější necitlivé zásahy do krajiny (jako příklad se uvádí, že ve 20. století byla celková délka vodních toků $\mathrm{v}$ České republice zkrácena o jednu třetinu ${ }^{40}$ ) si žádají nápravu, revitalizaci a 
dlouhodobě udržitelné řešení. Většinou vědecká agenda doporučuje řadu drobných dílčích změn na lokální úrovni.

Nedostatečnou retenční schopností krajiny je ohrožený nejenom vodní režim, ale vzhledem k již zmíněné úzké provázanosti prvků ekosystémů také úrodnost půdy (zvýšené nebezpečí vodní eroze úrodné vrstvy dané extrémními průtoky). Schopnost účinně v krajině zadržovat vodu a její zvyšování je tedy „obecně žádoucí, nebot' vede ke zmírnění dopadủ hydrologických extrémů (povodní i sucha), ke zlepšení jakosti vod a ke zvýšení biologické i rekreační hodnoty krajiny““. ${ }^{41}$

Pokud jde o původ vědeckých studií o zadržování vody v krajině, bývají iniciovány nikoli globálními či regionálními zprávami (jako u globálních změn klimatu), ale spíše jde o problematiku nastolovanou na lokální úrovni. Impulsem mohou být povodně, ale například také snižování hladiny podzemní vody. ${ }^{42}$

Tabulka 1: Př́íciny aktuálního nedostatku vody ve světě

\begin{tabular}{|l|c|}
\hline \multicolumn{1}{|c|}{ Příčiny } & Zasažená oblast \\
\hline Znečišt'ování vodních zdrojů & Čína $^{43}$ \\
\hline Globální oteplování & $?$ \\
\hline Vyčerpávání vodních zdrojů zavlažováním & Saúdská Arábie $^{44}$ \\
\hline Absence vodních zdrojů v oblasti & Malta $^{45}$ \\
\hline Ztráta schopnosti krajiny zadržovat vodu & Indie $^{46}$ \\
\hline Chybějící vodní infrastruktura & Sierra Leone $^{47}$ \\
\hline Desertifikace & Sahel $^{48}$ \\
\hline
\end{tabular}

Zdroj: autor.

Dosud jsme se zabývali pouze přírodovědeckými studiemi, které hodnotí pouze přímé dopady změn v hydrologické bilanci. Tyto změny však mohou vyvolat i společenské změny. Přírodní a společenské vědy jsou ovšem u nás dosti striktně oddělovány a komplexní studie možných společenských dopadů nedostatku vody (jako např́klad důsledku klimatických změn) dosud chybí. V zahraničí podobná literatura existuje, jsou zpracovávány studie možných společenských dopadů pro oblasti, kde je již dnes vody relativní nedostatek (severní Afrika, Blízký východ, některé části Číny aj.) a existuje i několik globálních prognostických studiui ${ }^{40}{ }^{50}$. Poměrně rozsáhlá je i literatura o vazbě mezi nedostatkem vody a násilnými konflikty (šíře problému i základní souvislosti jsou přehledně zachyceny v diagramu 3). Koncept konfliktů o vodu je v zahraničí často diskutován ${ }^{51}$.

I několik českých vědců (především z oboru mezinárodních vztahů) se věnuje problému nedostatku vody $\mathrm{v}$ zahraničí ${ }^{53}$, českému (či středoevropskému) prostředí se však vyhýbají. Důvodem bude patrně především relativní dostatek vody vČeské republice v porovnání s pouštními a polopouštními oblastmi. Toto chápání problematiky dokládá např́íklad M. Romancov vyjádřením v úvodu svého článku o významu vody jako suroviny: „Voda je, jakkoli se to z naši středoevropské perspektivy může jevit jinak, tou nejdůležitějši strategickou surovinou. “54

Jestliže se ovšem podíváme na prognózy vývoje bezpečnostního prostředí a bezpečnostních hrozeb, nalezneme několik varovných zmínek ve střednědobých a výhledových studiích ${ }^{55} 5657$. Význam přisuzovaný hrozbě nedostatku není v porovnání s dalšími hrozbami příliš vysoký. Vnímaná nebezpečnost je ovlivněná také tím, že vývoj změn globálního klimatu (jako nejčastěji zmiňované příčiny nedostatku vody) je nejistý a dopady jsou patrně chápány jako vzdálené. 


\section{Diagram 3: Nedostatek vody a násilné konflikty}

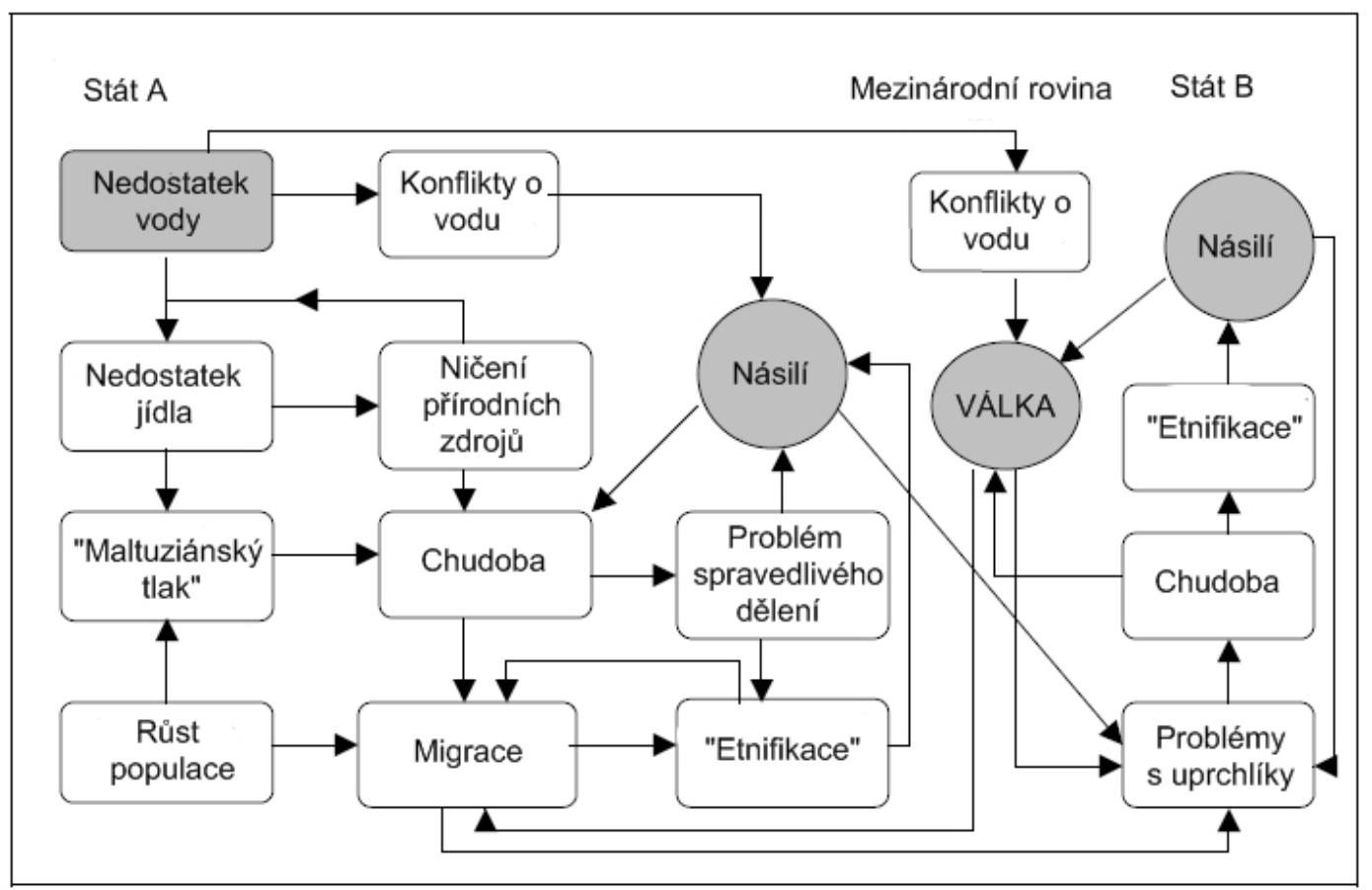

Zdroj: MOLLER, Bjorn. Fresh Water Sources, Security and Conflict: An Overview of Linkages, s. 22.

\section{Shrnutí kapitoly}

U př́rodovědecké komunity je tedy téma nedostatku vody nejčastěji nastolováno $\mathrm{v}$ souvislosti s globálními změnami klimatu. I když se někdy uvádí, že „,celkově se však počasí [následkem klimatických změn] $v \check{C} R$ spíše zlepši “58, panuje shoda na jedné výjimce: „Oteplení přinese $i$ vysoušení. Voda bude cennější. Hospodaření s vodou v krajině se stane limitujicím faktorem udržitelného rozvoje. " ${ }^{59}$ Dopady na hydrologickou situaci by tedy tvořily převážnou část přímých negativních důsledků globálních změn klimatu pro Českou republiku.

Významným problémem, který ohrožuje dostupnost kvalitní vody v dostatečném množství, je znečištování vody. I přes výrazný posun od stavu před rokem 1989 zdaleka nedošlo k vyřešení všech problémů. Dále se nedostatek vody objevuje jako možný důsledek narušením retenčních schopností krajiny. Tento problém je u nás spojen především se široce diskutovaným tématem povodní. Problémem je i dostupnost vody v místě, kde je potřeba. Výše zmíněný příklad Prahy ukazuje, že tento problém je do určitého stupně překonatelný, nicméně nese to s sebou určité limity a hrozby.

Celkově je tedy česká přírodovědná agenda k problému nedostatku vody pozorná, především jako k možnému nejpalčivějšímu důsledku klimatických změn. Otázka znečištování vody je pak řešena spíše v rámci již ustavených vodohospodářských institucí, nikoli primárně vědeckou obcí.

Pokud jde o prognostické sociálněvědní studie, téma nedostatku vody se v nich nejčastěji objevuje také v souvislosti s možnými změnami klimatu. Jak ale vyplývá z výše uvedeného, společenským dopadům se v našem prostředí věnují daleko více přírodovědci. Do sociálních věd téma nedostatku vody proniká jen velmi pomalu.

Nejčastěji uváděné hodnoty ohrožené přímými dopady možného nedostatku vody jsou shrnuty v diagramu 4 . Ze schématu je patrné, že menší nedostatek vody narušuje části životního prostředí a 
závažnost dopadů pro lidskou společnost roste s tím, jak dostupné vody v prostředí celkově ubývá. Postupně je tak ohroženo i zdraví (v případě nedostatku vody pro hygienické účely) i život (nedostatek pitné vody). Dopady na různé referenční objekty se přitom sčítají, což umožňuje předpokládat výraznou postupnou akceleraci hrozby a dominový efekt. K tomuto rysu hrozby nedostatku vody se ještě vrátíme v závěru této práce.

\section{Diagram 4: Nedostatek vody a ohrožené hodnoty}

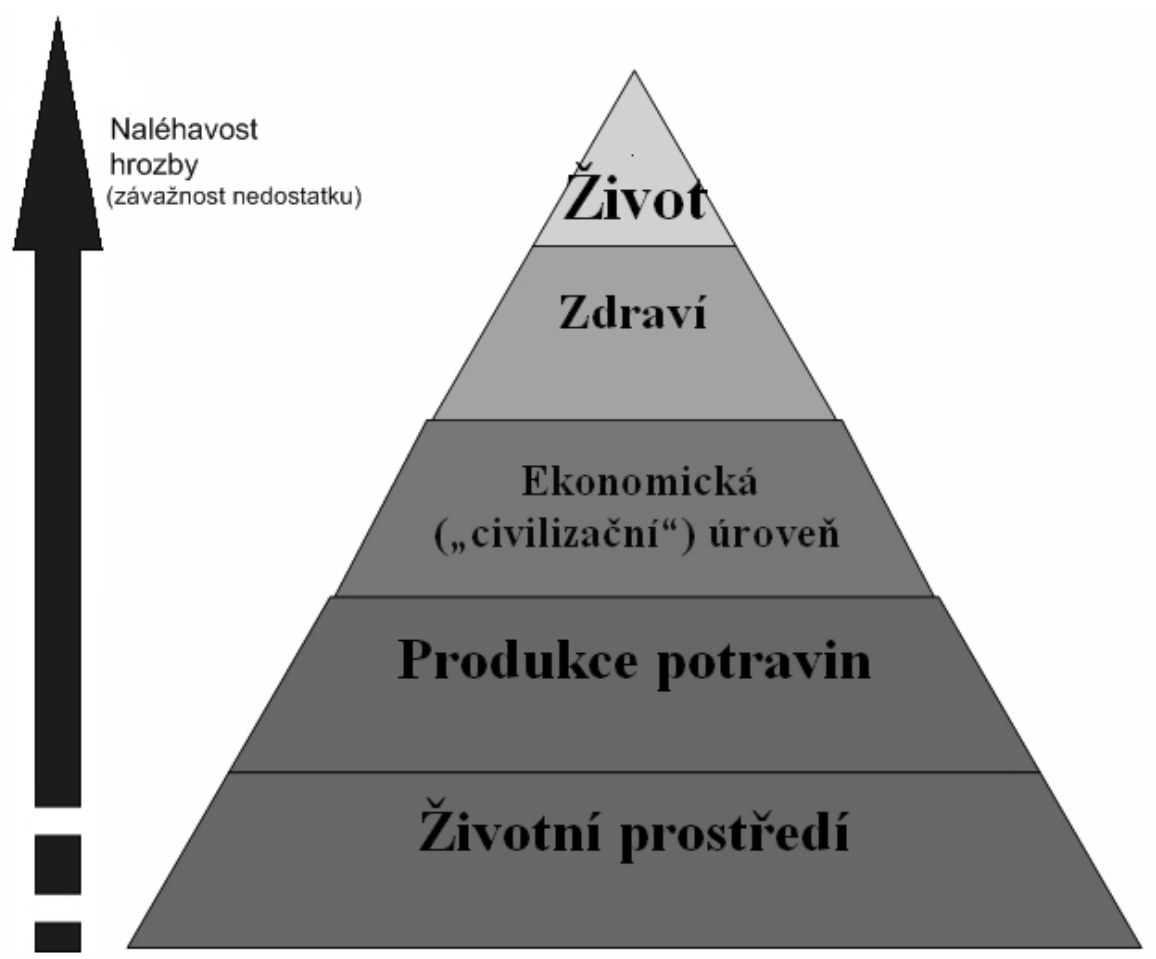

Zdroj: autor.

Ve vědecké agendě lze vypozorovat určité trendy, které lze vykládat jako navrhovaná opatření proti možnému nedostatku vody. Jedná se především o:

1. Trend revitalizace krajiny a obnovy její přrirozené funkce,

2. Trend snižování spotřeby vody,

3. Trend ochrany kvality vody.

Probíhá také diskuse ohledně nutnosti technických adaptačních opatření velkého rozsahu (např. přehrad) a jejich místa $v$ celkové strategii předcházení nedostatku vody. Zatímco někteří odborníci pokládají případné budování přehrad pouze za doplněk revitalizačních snah ${ }^{60}$, jiní poukazují na naprostou nezbytnost nových nádrží pro udržení stabilní hydrologické bilance ${ }^{61}$.

Konkrétní kroky a strategie pro snižování rizika nedostatku vody (a tedy praktický odraz těchto trendů) si přiblížíme v následujících kapitolách v souvislosti s politickou agendou.

\section{SEKURITIZAČNÍ AKTÉŘI HROZBY NEDOSTATKU VODY V ČR}

Zatímco v předchozí kapitole jsme se zabývali tím, kdo na hrozbu nedostatku vody upozorňuje, nyní se zaměříme na sekuritizační aktéry této hrozby, tj. na jedince či instituce, kteří prosazují 
nedostatek vody do bezpečnostní agendy. Zde je nutné pamatovat na vymezení sekuritizace. Sekuritizace nenastává vždy, když je určité téma označeno za „bezpečnostní“ a naopak ne všechna sekuritizovaná témata jsou ve společnosti chápána jako „bezpečnostní“. Podstatné je „určení existenčních hrozeb, jež vyžadují mimořádný zákrok či zvláštní opatření“62. V našem výzkumu tedy nejde o to nacházet spojení nedostatku vody se slovem bezpečnost, ale o chápání nedostatku vody jako existenční hrozby a v př́ípadě sekuritizačních aktérů i o navrhování mimořádných opatření. Tato kapitola se snaží najít sekuritizační aktéry zkoumané hrozby v českém prostředí.

\section{Nevládní neziskové organizace}

Významnou roli v sekuritizaci environmentálních hrozeb hrají nevládní neziskové organizace. Především ekologické skupiny vyvíjejí nátlak na odpovědné orgány a zároveň představují určité téma široké veřejnosti. Pokud tyto skupiny upozorňují na neodvratnost a existenční charakter hrozby a zároveň navrhují (alespoň v obecné rovině) použití nestandardních prostředků k eliminaci hrozby, jde o typický př́́klad sekuritizačních aktérů. Vzhledem k tomu, že velká část ekologických NGOs zaměstnává vlastní vědce ${ }^{63}{ }^{64}$ a jejich pracovníci často působí přímo v terénu, hrají NGOs důležitou roli i při nastolování nových témat.

\section{Výsledky průzkumu ve sfére nevládních neziskových organizací}

Po prozkoumání materiálů jednotlivých NGOs a vyhodnocení dotazníkového šetření lze konstatovat, že důsledné sekuritizační snahy nevyvíjí žádná nezisková nevládní organizace v České republice. Nejblíže k typické „gramatice bezpečnosti “65 environmentálních hrozeb má Greenpeace, ovšem ani Greenpeace nenavrhuje mimořádná opatření překračující sféru běžné politiky. Jde spíšs tedy o potvrzení správnosti a nutnosti stávajících snah organizace (snižování emisí, zablokování těžby uhlí apod.) poukazováním na to, co by se případně mohlo stát, pokud by tyto snahy neuspěly.

Sekuritizace nedostatku vody ekologickými NGOs není tudíž v České republice prosazována. Dotazovaní zástupci jednotlivých NGOs zabývajících se dostupností a kvalitou vody v krajině (Arnika, Hnutí Duha aj.) se vcelku shodují, že není vhodné z problematiky nedostatku vody dělat bezpečnostní téma ${ }^{66}$.

\section{Mapa 1: Prognóza vývoje suchých oblastí v následujících 20 letech}

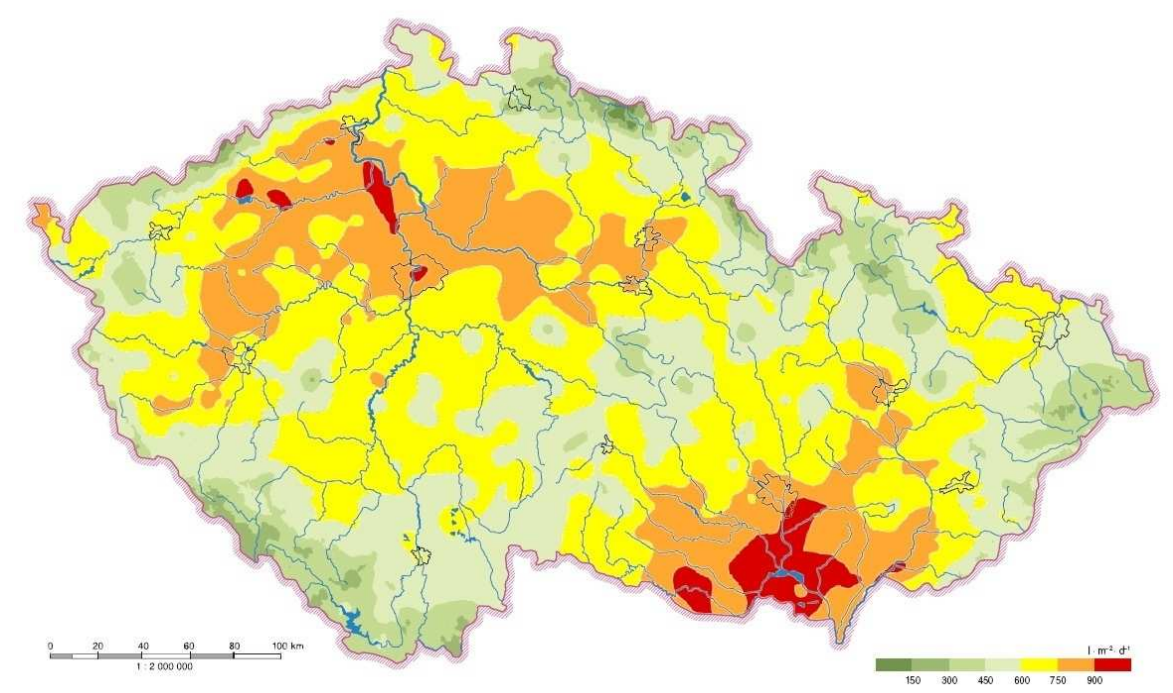

Zdroj: PETRŽÍLEK, Petr. Nedostatek vody a sucho - Opatření navrhovaná ČSSD $k$ zmírnění dopadi̊ klimatických změn. 
Velkou podporu pro politizační a sekuritizační snahy na druhou stranu dávala najevo sdružení, která by sama sekuritizaci tohoto tématu neprosazovala. Například občanské sdružení Jihočeské matky odpovídá, že se „jedná o klíčový problém na Zemi, rozhodně by se mu méla plně a urychleně věnovat pozornost na všech úrovních států, Evropy“68, podobně např́íklad Pražské matky a jejich odpověd' na otázku o nutnosti zařazení tématu nedostatku vody do bezpečnostní agendy: „Ano, a především by měli být formou kampaní atd. informováni občané, kteři často nemají o nutnosti šetření vodou ani potuchy. Za velmi důležitou považuji také osvětu ve školách tlačit to do hlavy dětem - soutěže, projekty... " ${ }^{69}$ I další NGOs (např. Rosa, LEA, Přátelé přírody, ...) odpovídaly na otázku, zda se tématem zabývají, záporně, přesto následně v další otázce odpovídají kladně na dotaz o nutnosti zařazení tématu do bezpečnostní agendy České republiky. Analýza důvodů a motivů této podpory by si jistě zasloužila zvláštní studii.

\section{Politické strany}

V této podkapitole shrnu výzkum vnímání hrozby nedostatku vody politickými stranami v České republice. Budu hledat odpověd' na otázku, do jaké míry se tomuto tématu strany (či jednotliví členové) věnují a zda vyvíjí sekuritizační snahy.

\section{Výsledky průzkumu ve vztahu k politickým stranám}

Nedostatku vody se programově nejvíce věnuje ČSSD. Růst zájmu o tuto problematiku je patrný především v poslední době. Zjištěná data ukazují, že spouštěcím momentem byla zpráva vzešlá od části globální vědecké komunity (4. zpráva IPCC). Reflexe této hrozby tak patrně nebyla iniciována závěry českých vědců.

Česká strana sociálně demokratická (dále ČSSD) posiluje „ekologickou“ část svého programu, především v reakci na zprávy IPCC a jejich implikace pro střední Evropu ${ }^{70}$. I když dlouhodobý program ČSSD uvádí nutnost „zvýšené péče o čistotu a kvalitu povrchových a podzemních vod“71, teprve v poslední době toto velmi obecné stanovisko nabírá konkrétních podob. Zároveň se začíná upozorňovat na nedostatek vody, který se podle vyjádření stínového ministra životního prostředí Petra Petržílka stává „centrálním tématem naši ekologické politiky“. ${ }^{72}$ Toto téma bylo prý již několikrát projednáváno na politickém grémiu a ve stínové vládě ČSSD ${ }^{73}$.

Ostatní v Poslanecké sněmovně zastoupené strany se zkoumanému tématu nevěnují v námi vymezené rovině, nedostatek vody není pojímán jako samostatné téma, nýbrž většinou jako potenciální následek nezvládnutí jiných problémů.

Strana zelených (dále SZ) jako typická politická strana environmentálního zaměření se ochraně přírody a problémům z poškozovaní životního prostředí plynoucím věnuje velmi podrobně. Pokud jde konkrétně o hrozbu nedostatku vody, v programu SZ pro parlamentní volby $2006^{74}$ však nelze nalézt zmínku o této hrozbě. Přesto jsou dưrazně a na více místech navrhována opatření ke zvýšení retenčních schopností krajiny, např́klad z důvodu posílení samočisticí schopnosti vod ${ }^{75}$, zabránění povodním $^{76}$ a snížení eroze půdy ${ }^{77}$.

ODS vyjasněný postoj k environmentálním hrozbám nemá. Senátor Bedřich Moldan upozorňuje především na možná sucha v souvislosti s globálními změnami klimatu ${ }^{78} 79$. Část ODS se (pravděpodobně i vlivem názorů V. Klause) o klimatických změnách vyjadřuje dosti skepticky ${ }^{80}$ 818283 , i když na druhou stranu Moldan rozhodně není ve svých názorech o nezpochybnitelnosti globálního oteplování osamocen ${ }^{84}$. Pevný, jasný a především jednotný postoj ODS k tomuto tématu tedy nemůžeme vysledovat.

Komunistická strana Čech a Moravy (dále KSČM) se tematikou nedostatku vody ve svém programu nezabývá. Volební program pro volby do Poslanecké sněmovny z roku 2006 se omezuje pouze na konstatování, že KSČM prosazuje „optimální ochranu a obnovu vod“. ${ }^{85}$ Velmi podobné formulace obsahuje i nevolební program Naděje pro Českou republiku ${ }^{86}$. 
Křest’anská a demokratická Unie - Čs. strana lidová (dále KDÚ-ČSL) se ve svých programových dokumentech zmiňuje o hrozbě nedostatku vody pouze okrajově. Většina opatření pro změnu vodního režimu v krajině je navrhována za účelem předcházení povodním, případně jako opatření pro zvýšení a udržení jakosti pitné vody ${ }^{87}$. KDÚ-ČSL také vnímá propojení problému zásobování s vodou a globálních změn klimatu ${ }^{88}{ }^{89}$. Dál se KDÚ-ČSL věnuje regionálním problémům s vodou a jejím nedostatkem. Prioritou místního programu KDÚ-ČSL pro komunální volby v roce 2006 v Mostech u Jablunkova ${ }^{90}$ bylo např́klad zajistit dostatek vody pro tuto obec. Podobně se i senátor za KDÚ-ČSL Petr Pithart zabýval ve svém volebním obvodu i nedostatkem vody v osadě Vížky (Lukavice) $)^{91}$.

Důslednou sekuritizační snahu tedy u žádné politické strany zatím nepozorujeme, chybí především fáze veřejného diskurzu a tvorby konkrétních bezpečnostních politik pro danou oblast.

\section{Státní správa}

Státní (veřejné) orgány mohou být významnými funkcionálními, ale také sekuritizačními aktéry hrozby nedostatku vody. Následující podkapitola shrne výsledky analýzy relevantních dokumentů v této oblasti.

\section{Výsledky průzkumu ve sfére státní správy}

Klíčovou roli při sekuritizaci určitého tématu hraje vláda. V základním dokumentu týkajícím se bezpečnosti, Bezpečnostní strategii, nalezneme jen okrajovou zmínku o vodě jako možné prř́čině konfliktů v méně rozvinutém světě ${ }^{92}$. Další strategické dokumenty, byt' ne již ryze bezpečnostního charakteru, zmiňují význam vody ${ }^{93}$. Základním a nejdůležitějším strategickým dokumentem státní politiky v oblasti vod je Plán hlavních povodí České republiky. Prosazovaná opatření se pohybují ve sféré politizace. Nedostatek vody není chápán jako bezpečnostní problém, sucho je podle této koncepce , běžným, normálním a opakujícím se klimatickým jevem “.94

Velmi významnou úlohu ve vodohospodářském sektoru hraje Ministerstvo zemědělství (dále jen MZe) jako ústř̌ední orgán státní správy pro vodní hospodářstvi 95 . Různé koncepce a strategické dokumenty MZe přikládají vodě velký význam a tvrdí, že je „nejzávažnějším limitujícím faktorem růstu produkce “.96 I když základní úkol ministerstva v této oblasti je pozitivní - zajištění vody v dostatečném množství a kvalitě, můžeme to stejně tak chápat jako předcházení nedostatku vody k různým účelům. Nedostatek vody je tak tématem, kterému se vodohospodáři každý den věnují. Dokládá to vysokou míru institucionalizace hrozby, což má pro výzkumné otázky této práce vysokou důležitost. Rozvedení této problematiky se budu věnovat v závěru této podkapitoly.

Kromě MZe a Ministerstva životního prostředí sehrávají klíčovou roli také státní podniky Povodí jako přímí správci toků a státního majetku v hodnotě okolo 40 miliard korun. ${ }^{97}$

O zásobování domácností vodou se starají především jednotlivé firmy vodovodů a kanalizací. Význam vodovodů a kanalizací dokládá hodnota infrastrukturního majetku, která přesahuje 820 miliard korun ${ }^{98}$. Podniky vodovodů a kanalizací však rozhodně nevystupují jako sekuritizační aktéŕi, i když významnými funkcionálními aktéry rozhodně jsou.

Nedostatek vody je i jedním z témat krizového řízení. Dvě typové krizové situace, Znečištění vody, ovzduší a prrírodního prostředí haváriemi velkého rozsahu a Narušení dodávek pitné vody velkého rozsahu, mohou být chápány jako jasný důkaz úspěšné sekuritizace nedostatku vody upozorňuje se na existenční hrozbu a jsou ospravedlněna mimořádná opatření.

Zkoumané strategie a koncepce tedy ukazují, že vědeckou komunitou nastolená témata se dostávají do povědomí funkcionálních aktérů a minimálně „na papír“ příslušných institucí. Vzhledem k dosaženým poznatkům o politizačních a sekuritizačních snahách politických stran a NGOs lze vyvozovat, že komunikace mezi vědeckou komunitou a vodohospodáři probíhá často přímo a pod úrovní centrální politické sféry. Určité impulsy přicházejí také od $\mathrm{EU}^{99}$. 
Důležitým zjištěním této podkapitoly je důsledná institucionalizace zkoumané hrozby, což je pro environmentální sektor bezpečnosti zvláštní1 ${ }^{100}$. I když v porovnání s jinou hydrologicky extrémní situací - povodněmi - nemá nedostatek vody dostatečnou oporu v zákoně č. 254/2001 Sb. o vodách, existence krizových plánů dokládá velkou pozornost věnovanou případnému řešení problému. Chybějící pevné zakotvení v zákonné normě však může být překážkou důsledného plánování a př́ípravě preventivních opatření.

Nejdůležitějším poznatkem je však pozice hrozby nedostatku vody v systému krizového řízení. Zařazení zkoumané problematiky do krizových situací nám dává možnost přemýšlet o hrozbě nedostatku vody jako o již dříve úspěšně sekuritizovaném tématu.

\section{Poznatky z průzkumu nedostatku vody}

Buzan, Waever a de Wilde tvrdí, že snahy o sekuritizaci environmentálních hrozeb „narážejí kromě jiného na skutečnost, že hrozby tohoto typu jsou nové (připadně nově objevené) a s ohledem na svou existenční naléhavost kontroverzní. V důsledku toho tyto snahy (ještě) nedošly svého institucionálního vyjádření a pohybují se v politickém kontextu, v němž převládaji bezpečnostní instituce navržené pro zvládání jiných druhů hrozeb “. ${ }^{101}$ My jsme však v této kapitole viděli velmi rozsáhlou sít' institucí, která má zabezpečit (především na úrovni politizace) vhodné hospodaření s vodou, a tedy i předcházení jejímu nedostatku. Hrozba nedostatku vody tak nemůže být chápána jako klasický př́klad hrozby v environmentálním sektoru, nebot' nejde o hrozbu ,novou (nově objevenou)“ ani neinstitucionalizovanou. To je velmi důležitý poznatek, který by mohl rozšririit vnímání hrozeb environmentálního sektoru Kodaňskou školou. Pro tuto práci je však toto zjištění klíčové z toho důvodu, že institucionalizace hrozby přenáší velkou část odpovědnosti za hodnocení i zvládání rizika na zrrízené instituce. To je nejlépe patrné „,ve vojenském sektoru: státy odnepaměti čelily hrozbě ozbrojeného nátlaku či invaze a v rámci svých reakcí vybudovaly stálé administrativní aparáty, procedury a vojenské složky, jejichž prostřednictvím hodlají tyto hrozby zvládat. Přestože „proceduralizace“ zdánlivě vrací bezpečnost na úroveñ standardní politiky, ve skutečnosti tomu tak není “. ${ }^{102}$ To tedy ukazuje na to, že sekuritizační proces v tomto oboru mohl proběhnout již dřive, a z toho důvodu v současnosti nemusíme pozorovat všechny atributy sekuritizačního procesu popsané Buzanem, Waeverem a de Wildem ani nemusíme čekat z důvodu nezahrnutí do „zavedených ekonomických a politických zvyklostí a postupư“103 snahu „radikálně nadsazovat skutečný význam ... hodnot a témat" ${ }^{104} \mathrm{~V}$ nejobecnější rovině by tedy tento poznatek dovoloval formulovat tvrzení, že i přes absenci konkrétních výrazných sekuritizačních kroků je téma nedostatku vody v České republice sekuritizováno. Důkazem toho by mohla být právě důkladná institucionalizace hrozby. O obhajitelnosti tohoto tvrzení ještě pojednám v závěru práce.

Lze tedy konstatovat, že politizace a případně sekuritizace hrozby nedostatku vody má odraz nejen v konkrétních přijatých dokumentech a strategiích, ale i ve formě struktury institucí pro zvládání hrozby. V podmínkách České republiky je tedy nedostatek vody jedinou environmentální hrozbou, u které lze pozorovat důslednou institucionalizaci na celostátní úrovni.

Pro tento výzkum plyne z vysoké míry institucionalizace hrozby také to, že sekuritizační aktéři mohou působit přímo na příslušné odpovědné instituce. Pokud tedy nejsou navrhována mimořádná opatření (tato práce nic takového u zkoumaných aktérů nepotvrdila), sekuritizační aktér se může obejít bez předložení tématu širokému publiku (laické veřejnosti) a obrátit se přímo na veřejnost odbornou. Proces přijetí nastoleného tématu (jako vyvrcholení sekuritizačních snah) tudíž může probíhat uvnitř výše nastíněné struktury bez přímé účasti široké veřejnosti.

Bez přímé legitimizace před veřejností se obejde i zařazení hrozby nedostatku vody do krizových plánů. Krizové situace ospravedlňují okamžité zásahy př́íslušných výkonných orgánů, přičemž předložení relevantnímu publiku (nebo i schvalování zákonodárnou mocí) by mohlo zdržet nutné akce a způsobit velké škody z prodlení. Celkově je systém řízení v krizových situacích většinově schvalován, at' už politickými stranami, tak společností obecně. 
Veřejnému mínění zatím k posouzení hrozba nedostatku vody dána nebyla. V současnosti není nedostatek vody ve společnosti př́liš reflektován, jak ukazují celostátní i úžeji zaměřené výzkumy veřejného mínění ${ }^{105}{ }^{106}{ }^{107}$. Jestliže je nedostatek vody chápán jako hrozba, je tím myšlen především nedostatek vody mimo území České republiky a jeho důsledky ${ }^{108}$.

\section{ZÁVĚR}

Tato práce se pokusila zmapovat průběh a hlavní aktéry sekuritizačního procesu hrozby nedostatku vody v České republice. Data shromážděná a analyzovaná v předchozí části výzkumu nám dovolují formulovat odpovědi na základní výzkumné otázky. Dále se zde zaměřím i na celkové shrnutí, evaluaci zvoleného postupu práce a nastínění problematických oblastí vhodných k dalšímu výzkumu.

\section{Výzkumné otázky}

\section{Je hrozba nedostatku vody v České republice sekuritizována?}

Na základě zjištěných dat o možných sekuritizačních aktérech, o jejich mínění a v souladu s poznatky z analýzy strategických dokumentů lze tvrdit, že sekuritizační proces hrozby nedostatku vody v České republice aktuálně neprobíhá. Přestože je zkoumaná hrozba často zmiňována jako jeden z možných důsledků nezvládnutí současných problémů (globální změny klimatu, porušení krajiny a jejich základních funkcí, znečišt'ování životního prostředí...), žádný aktér nevyvíjí snahu sekuritizovat tuto problematiku jako hlavní problém a přímou existenční hrozbu a navrhnout mimořádná opatření k jejímu zvládnutí. A právě takové jsou podmínky sekuritizace, které tedy, jak vidíme, v České republice chybějí.

Pokud ale budeme chápat sekuritizaci nikoli jako proces, nýbrž jako stav, odpověd’ na základní výzkumnou otázku může být naprosto odlišná. V předchozí kapitole jsme viděli, že k zajištění dostatku vody stát zřizuje velké množství institucí a existuje poměrně rozsáhlá legislativa o nakládání s vodami. Tato institucionální struktura vyjadřuje vysokou míru politizace problematiky.

O vnímání vážnosti důsledků nedostatku vody svědčí i zařazení této hrozby mezi situace vyžadující krizové řízení. Krizové řízení zahrnuje vždy odkaz na dvě nutné, základní podmínky sekuritizace - existenční hrozbu a mimořádná opatření. Krizové plány představují snahu co nejvíce přiblížit zvládnutí sekuritizované hrozby standardnímu procesu řešení problémů v rámci politizace. Do krizových plánů je zařazen především nedostatek pitné vody, nikoli nedostatek vody v krajině apod. Lze tedy říci, že téma nedostatku vody je v České republice částečně sekuritizováno. Č́stečně znamená, že pouze vzhledem k určitým referenčním objektům (lidem), zatímco ve vztahu k dalším referenčním objektům nikoli - viz dále.

\section{Kdo se v sekuritizačním dění angažuje?}

- Kdo téma nastoluje?

- Kdo jsou nejvýznamnější sekuritizační aktéři?

- Kdo jsou nejvýznamnější funkcionální aktéři?

Pokud jde o nastolování tématu, viděli jsme, že nejčastěji je nedostatek vody spojován s globálními změnami klimatu. Předcházení znečištování vody je dnes chápáno spíše jako práce pro vodohospodářské instituce a ministerstvo životního prostředí, nebot' př́rodovědný výzkum v této oblasti už poskytl dostatek poznatků pro praktickou aplikaci nutných opatření (stále probíhá vědecká diskuse především o nových typech znečištění, například pohlavními hormony $\mathrm{z}$ antikoncepce, antibiotiky apod.) ${ }^{109}$.

Klasického sekuritizačního aktéra tento výzkum v České republice mezi nevládními organizacemi, politickými stranami či státními institucemi nenalezl. Ačkoli většina zkoumaných a 
dotazovaných aktérů mluví o nutnosti zařadit téma nedostatku vody do bezpečnostní agendy (a tedy v podstatě přijímá první předpoklad sekuritizace - existenční charakter hrozby), mimořádná opatření nad rámec klasických politických postupů nejsou nikým navrhována. Mimořádná opatření jsou zahrnuta pouze v krizových plánech.

\section{Ve vztahu ke komu je sekuritizace prosazována?}

Tato výzkumná otázka se ptá na referenční objekty hrozby nedostatku vody. V drtivé většině aktéři zkoumaný problém chápou jako hrozbu pro obyvatele České republiky. Hrozba není vnímána jako existenční ohrožení pro celý stát - ale pro jedince (jeho život a zdraví) a dosaženou ekonomickou a životní úroveň. Dokonce i zkoumané ekologické NGOs zdůrazňují rizika plynoucí z problému pro lidskou společnost. Diagram 4 tak odráží převládající mínění většiny zkoumaných aktérů.

\section{Jak je sekuritizace této hrozby institucionalizována?}

V závěru předchozí kapitoly jsme tuto otázku zodpověděli téměř detailně. Institucionalizace této hrozby je na národní a nižší úrovni velmi silná. Majetek státem či obcemi budovaných struktur sloužící k zajištění dostatku vody přesahuje bilion korun. Dalším důkazem velké pozornosti je např́íklad to, že přes $40 \%$ všech prostředků na ochranu životního prostředí směřuje na ochranu $\operatorname{vod}^{110}$.

\section{Jaké jsou význačné rysy hrozby samé, které ovlivňuji sekuritizaci?}

Odpověd' na tuto otázku lze poskytnout na základě zkoumaných dokumentů a výpovědí aktérů. Hrozba nedostatku vody se zdá méně pravděpodobná, především jestliže vezmeme v úvahu dramatický pokles odběru a spotřeby vody od roku 1989. Naopak lokální problémy se zásobováním vodou, vysychání studní $\mathrm{v}$ určitých lokalitách ${ }^{111}$ a trend pokračující urbanizace úvahy o nebezpečnosti hrozby podporují. Na území České republiky sucho v minulosti nepředstavovalo tak velkou hrozbu jako v některých oblastech Afriky či Asie. Otázka globálních změn klimatu je však „divokou kartou“ všech prognóz. Tyto změny a jejich dopady mohou podle dostupných informací situaci výrazně zhoršit i na našem území.

Lze také doplnit obecný poznatek o relativně nižší nebezpečnosti environmentálních hrozeb pro rozvinuté, bohaté země. S růstem bohatství společnosti roste nejenom množství prostředků, které lze věnovat na boj s hrozbou, ale také od určitého bodu klesá míra znečištění a roste zájem o ochranu životního prostředí (toto vyjadřuje tzv. Environmentální Kuznetsova křivka - viz diagram 5), což je výrazné preventivní opatření.

Specifikem České republiky, které zvyšuje zranitelnost, je již zmíněná pozice na „střeše Evropy“. Voda k nám přichází pouze ve formě srážek, které jsou vždy více či méně rozkolísané. Přítoky ze sousedních států (vodní toky jsou většinou stabilnějšími zdroji vody než srážky) jsou pouze minimální.

Další analýza zranitelností a význačných rysů hrozby je nad rámec úkolů této práce i nad možností společenskovědní analýzy. Přesto by propojení přírodovědných a společenskovědních poznatků mohlo přispět k lepšímu pochopení celého problému, jeho rozsahu i nebezpečnosti. Další výzkum v této oblasti, směřující přes analýzu k syntéze s cílem odhadu míry rizika, by byl bezesporu velmi přínosný. 


\section{Diagram 5: Environmentální Kuznetsova křivka}

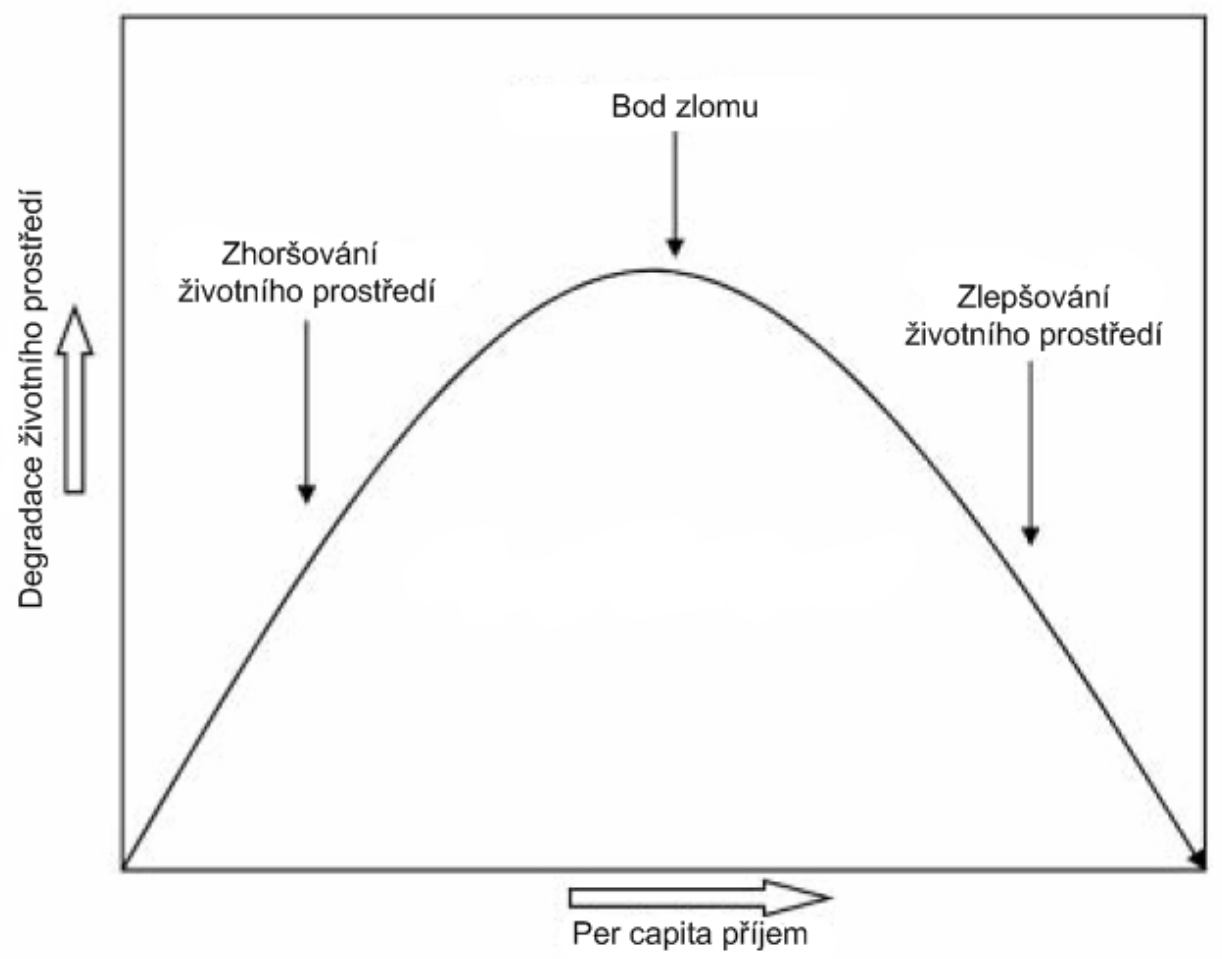

Zdroj: Environmental Kuznets Curves: A Review of Findings, Methods, and Policy Implications [online], s. 3.

\section{Závěrečné shrnutí}

Výzkum sekuritizace určité hrozby je v nejobecnější rovině odhalováním a konstrukcí schématu zahrnujícího samotnou „objektivní“ hrozbu (či její absenci), postoj a motivaci jednotlivých aktérů i odraz jednání těchto aktérů ve společnosti. Tyto jednotlivé složky sekuritizačního procesu propojuje velké množství vztahů, pro které jednoduchá linearita a kauzalita není vhodným vysvětlením.

V obecném povědomí převládá názor, že bezpečnost je „univerzální dobro“, „vytoužený konečný stav, k němuž by mělo veškeré dění směrovat “ ${ }^{112}$ Koncept sekuritizace však vystupuje proti tomuto zkreslujícímu pojetí - bezpečnost není objektivní stav, ale je to výsledek subjektivního, různě motivovaného jednání aktérů $\mathrm{v}$ určitých podmínkách dosahovaný „mimořádnou mobilizací státu “113 a velmi často také přerušením svobodné diskuse.

Zcela legitimní otázkou se proto stává, zda prínosy sekuritizace vyváží náklady. Např́ílad nadměrná sekuritizace ekonomických témat může vést $\mathrm{k}$ utlumení trhu a $\mathrm{k}$ poklesu celkové úrovně ekonomiky. Často se dokonce tvrdí, že „ústředním stavebním kamenem ideologie kapitalismu je právě desekuritizace ekonomiky “ " ${ }^{114}$ Dalším často diskutovaným problémem, který souvisí s riziky sekuritizace, je tzv. bezpečnostní dilema, tedy označení pro situace, kdy obava aktéra A z jednání aktéra B vyprovokuje preventivní akci (např́ílad zbrojení), na kterou aktér B musí reagovat, i když původně agresivní jednání neplánoval. Náklady na boj s terorismem se měří nejen finančními prostř̌edky, ale i mírou nutného narušení lidských práv a svobod. 
Buzan, Waever a de Wilde důrazně varují před chápáním bezpečnosti jako nejlepšího řešení pro všechny problémy společnosti. A přestože tedy sektorový přístup Kodaňské školy „otevírá dvírka k proliferaci sekuritizačních aktivit, jeho konstruktivistická metodologie poskytuje zároven̆ prostredky ke zpochybnéní a politizaci každého konkrétního př́padu sekuritizace “. ${ }^{115}$

V kontextu představovaného výzkumu je tedy třeba upozornit na fakt, že velká většina dotazovaných aktérů jako odpověd’ na otázku po vhodnosti zařazení nebezpečí nedostatku do bezpečnostní agendy (třetí otázka dotazníku, viz př́loha) odpovídá kladně. Přestože se najdou i výjimky (např. senátor Karel Šebek odpovídá: „K dobru věci není toto téma př́liš politizováno a prednost mají věcné a fundované názory “116), celkově lze z odpovědí vyvodit závěr, že snaha o zařazení tématu do bezpečnostní agendy je chápána povětšinou jako bezproblémová, a to v tom smyslu, že nejsou vnímaná výše uvedená rizika.

Bezpečnostní studia a výzkum sekuritizace tedy mají vysokou společenskou hodnotu v tom, že kriticky zkoumají proces transferu témat z politizační do sekuritizované sféry a mohou tak upozornit na nebezpečí tohoto přesunu a předejít zneužití moci, plýtvání prostředků a podobně. Zároveň mohou bezpečnostní studia pomoci při zpracovávání prognóz vývoje a společenských dopadů environmentálních hrozeb, což se zdá velmi důležité vzhledem k výhodnosti (či dokonce nutnosti) preventivního př́ístupu a včasného řešení tohoto typu hrozeb.

\section{POZNÁMKY}

${ }^{1}$ CÍLEK, Václav. Tsunami je stále s námi: eseje o klimatu, společnosti a katastrofách, s. 80.

${ }^{2}$ Safe Drinking Water [online], s. 6.

${ }^{3}$ HENDL, Jan. Kvalitativní výzkum: základní metody a aplikace, s. 110.

${ }^{4}$ Viz např. „Sekuritizace“, „Referenční objekty bezpečnostní politiky“ a „Činitelé bezpečnostní politiky“ ve sborníku: Česká bezpečnostní terminologie: výklad základních pojmì. Editor Petr Zeman.

${ }^{5}$ BUBLAN, František. Odpověd’ na zaslaný dotazník (ČSSD), 6. 3. 2008.

${ }^{6}$ Viz např́íklad: HLADNÝ, Josef. a kol. Dopady možné změny klimatu na hydrologii a vodní zdroje v České republice, s. 7.

${ }^{7}$ HENDL, Jan. Kvalitativní výzkum: základní metody a aplikace, s. 152.

${ }^{8}$ Dále v textu budu používat obvyklou anglickou zkratku NGOs: Non-Governmental Organizations.

${ }_{9}^{9}$ BUZAN, Barry, WAEVER, Ole, DE WILDE, Jaap. Bezpečnost: nový rámec pro analýzu, s. 89.

${ }^{10}$ Ibid., s. 88.

${ }^{11}$ Stanovisko k Zelené knize „Adaptace na klimatickou změnu v Evropě - možnosti pro postup EU“ [online].

${ }^{12}$ Green Paper - Adapting to climate change in Europe - options for EU action [online].

${ }^{13}$ Stanovisko k Zelené knize „Adaptace na klimatickou změnu v Evropě - možnosti pro postup EU“ [online], s. 2 .

${ }^{14}$ HLADNÝ, Josef. a kol. Dopady možné změny klimatu na hydrologii a vodní zdroje v České republice, s. 132.

${ }^{15}$ Ibid., s. 133.

${ }^{16}$ Ibid., s. 133.

${ }^{17}$ Ibid., s. 134.

${ }^{18}$ KALVOVÁ, Jaroslava a kol. Scénáre změny klimatu na území České republiky a odhady dopadi klimatické změny na hydrologický režim, sektor zemédělství, sektor lesního hospodářství a na lidské zdraví v ČR.

${ }_{19}$ Anotace úkolů 2006.

${ }^{20}$ FUKSA, Josef. Odpověd' na zaslaný dotazník (V. Ú. V. TGM), 26. 3. 2008.

${ }^{21}$ Ibid.

${ }^{22}$ MINISTESRTVO ŽIVOTNÍHO PROSTŘEDÍ ČR. Situační zpráva ke Strategii udržitelného rozvoje ČR, s. 91.

${ }^{23}$ V červnu 2009 nahrazen v IPCC Ladislavem Metelkou.

${ }^{24}$ STEJSKAL, Jan. Jan Pretel: Kjótský protokol nás zachránit žádným způsobem nemůže.

${ }^{25}$ PRETEL, Jan. Klimatická změna a její vlivy na vodní režim.

${ }^{26}$ Ibid.

${ }^{27} \mathrm{~V}$ podstatě jde o rozšîření a úpravu poznatků výše zmíněné studie J. Hladného a kol. 
${ }^{28}$ Zpřesnění dosavadních odhadů dopadů klimatické změny v sektorech vodního hospodářství, zemědělství a lesnictví a návrhy adaptačních opatření [online].

${ }^{29}$ Viz např.: CÍLEK, Václav. Tsunami je stále s námi: eseje o klimatu, společnosti a katastrofách.

${ }^{30}$ CÍLEK, Václav. Evropská žízeň.

${ }^{31}$ Ibid.

${ }^{32}$ Suburbanizace pražského okolí: dopady na sociální prostředí a krajinu [online].

${ }^{33}$ ŘíHA, Martin. Odpověd' na zaslaný dotazník (Společnost pro trvale udržitelný život), 5. 3. 2008.

${ }^{34}$ SEA - Strategic Environmental Assessment, tj. posouzení vlivů různých koncepcí na životní prostředí.

35 ŘíHA, Martin. Odpověd’ na zaslaný dotazník (Společnost pro trvale udržitelný život), 5. 3. 2008.

${ }^{36}$ Ibid.

${ }^{37}$ BLAŽEK, Tomáš. Odpověd' na zaslaný dotazník (Sdružení Krajina), 5. 3. 2008.

38 SYROVÁTKA, Oldřich, ŠíR, Miloslav, TESAŘ, Miroslav. Změna př́stupů ke krajině - podmínka udržitelného rozvoje.

${ }^{39}$ Ibid.

${ }^{40}$ Ibid.

${ }^{41}$ Optimalizace krajinné struktury z hlediska hydrologických režimů [online].

${ }^{42}$ PRÁVO: Podzemní vody dramaticky ubývá.

${ }^{43}$ CHINADAILY.COM. China says water pollution so severe that cities could lack safe supplies.

${ }^{44}$ MARTINOVSKÝ, Petr. Nedostatek vody.

${ }^{45}$ ENVIWEB.CZ. Jak ostrovní stát Malta získává pitnou vodu.

${ }^{46}$ POSTEL, Sarah. Last Oasis - Facing Water Scarcity, s. 36.

${ }^{47}$ Ačkoliv se o Sierra Leone ř́́ká, že jde o na vodu nejbohatší zemi v západní Africe, desetiletí neklidu a konfliktů vedly $\mathrm{k}$ tomu, že $\mathrm{v}$ zemi téměř neexistuje vodní infrastruktura a více než polovina obyvatel tohoto státu postrádá př́stup k pitné a užitkové vodě. (Zdroj: World Resources 2005 [online], s. 208-209.)

${ }^{48}$ Desertification - a threat to the Sahel [online].

${ }^{49}$ Viz např́íklad jedna z nejstarších globálních studií: World Water Resources and Regional Vulnerability: Impact of Future Changes [online] a další.

${ }^{50}$ STERN, Nicolas. The economics of climate change: the Stern review.

${ }^{51}$ Water Conflict Chronology [online].

${ }^{52}$ Water and Conflict [online].

53 Okrajově např. TOŠOVSKÁ, Eva. Environmentální bezpečnost, prvním významnějším počinem bylo monotematické číslo časopisu Mezinárodní politika 7/2004 věnované konfliktům o vodu.

${ }^{54}$ ROMANCOV, Michal. Voda: surovina strategičtější než ropa, s. 4.

${ }_{56}^{55}$ Bezpečnostní prognózy a realita [online], s. 27.

${ }^{56}$ Bezpečnostní budoucnost České republiky. Otázky, výzvy a problémy [online], s. 8, 38, 79, 176.

${ }^{57}$ KRÁSNÝ, Antonín, SOCHA, Oldřich. Možné vlivy bezpečnostního prostředí na Českou republiku a její ozbrojené síly, s. 8, 12 .

${ }^{58}$ KENDER, Jan. Voda v krajině, s. 203.

${ }^{59}$ Ibid.

${ }^{60}$ PRETEL, Jan. Změny klimatického systému [online], s. 43.

${ }^{61}$ HAMÁČKOVÁ, Eva. Evropa chce šetřit vodou, Česko budovat přehrady.

${ }^{62}$ BUZAN, Barry, WAEVER, Ole, DE WILDE, Jaap. Bezpečnost: nový rámec pro analýzu, s. 38.

${ }^{63}$ Stručná historie Greenpeace [online].

${ }^{64}$ RAUSITILIALA, Kal. States, NGOs, and International Environmental Institutions, p. 719.

${ }^{65}$ BUZAN, Barry, WAEVER, Ole, DE WILDE, Jaap. Bezpečnost: nový rámec pro analýzu, s. 37.

${ }^{66}$ BARTOŠOVÁ, Markéta. Odpověd' na zaslaný dotazník (Arnika), 11. 3. 2008.

${ }^{67}$ KOTECKÝ, Vojtěch. Odpověd’ na zaslaný dotazník (Hnutí Duha), 28. 3. 2008.

${ }^{68}$ SRNCOVÁ, Jitka. Odpověd' na zaslaný dotazník (Sdružení Jihočeské matky), 5. 3. 2008.

${ }^{69}$ ŠUCHMANOVÁ, Eva. Odpověd’ na zaslaný dotazník (Pražské matky), 5. 3. 2008.

${ }^{70}$ PETRŽÍLEK, Petr. Odpověd' na zaslaný dotazník (ČSSD), 27. 3. 2008.

${ }^{71}$ Dlouhodobý program - 6.3. Rozvoj zemědělství a venkova [online].

${ }^{72}$ PETRŽÍLEK, Petr. Odpověd’ na zaslaný dotazník (ČSSD), 27. 3. 2008.

${ }^{73}$ Ibid.

${ }^{74}$ Volební program Strany zelených „Kvalita života“ pro volby do Poslanecké sněmovny 2006 [online].

${ }^{75}$ Ibid., s. 24. 
${ }^{76}$ Ibid., s. 27.

${ }^{77}$ Ibid., s. 26.

${ }^{78}$ Přepis vystoupení B. Moldana v pořadu Otázky Václava Moravce [online].

${ }^{79}$ MOLDAN, Bedřich. Není to horor, ale skutečnost.

${ }^{80}$ KLAUS, Václav. Modrá, nikoli zelená planeta: co je ohrožen: klima, nebo svoboda?

${ }^{81}$ ŘíMAN, Martin. Př́roda nepochybně přežije. My však ne.

${ }^{82}$ Environmentalismus - rozumná politika nebo další pokus o omezování osobní svobody? [online].

${ }^{83}$ MUNDIL, Stanislav. Topolánek se chce změnám klimatu věnovat dřiv než socialisté.

${ }^{84}$ Petr Gandalovič: Online rozhovor[online].

${ }^{85}$ Volební program KSČM pro volby do Poslanecké sněmovny z roku 2006 [online].

${ }^{86}$ Naděje pro Českou republiku - nevolební program KSČM [online].

${ }^{87}$ Moderní ekologická politika KDU-ČSL [online].

${ }^{88}$ Ibid.

${ }^{89}$ SLAVOTÍNEK, Rostislav. Odpověd’ na zaslaný dotazník (KDÚ-ČSL), 5. 3. 2008.

${ }^{90}$ Třetí předvolební zpravodaj KDU-ČSL [online].

${ }^{91}$ Návštěvy volebního obvodu 2006 [online].

${ }_{92}$ Bezpečnostní strategie České republiky, s. 10.

${ }^{33}$ Např. Surovinová politika v oblasti nerostných surovin a jejich zdrojů [online], Strategie udržitelného rozvoje České republiky [online].

${ }^{94}$ Plán hlavních povodí České republiky [online], s. 63.

${ }^{95}$ Pro většinu činností, dle zákonů č. 2/1969 Sb. a 272/1996 Sb.

${ }^{96}$ Koncepce agrární politiky České republiky 2004 až 2013 [online], s. 3.

${ }^{97}$ Zpráva o stavu vodního hospodářství 2006 [online], s. 23.

${ }^{98}$ Vodovody a kanalizace 2006 [online], s. 14.

${ }^{99}$ Především naplňování Rámcové směrnice pro vodní politiku ES z roku 2000.

${ }^{100}$ BUZAN, Barry, WAEVER, Ole, DE WILDE, Jaap. Bezpečnost: nový rámec pro analýzu, s. 40.

${ }^{101}$ Ibid.

102 Ibid., s. 39.

${ }^{103}$ Ibid., s. 90.

${ }^{104}$ Ibid., s. 90.

${ }^{105}$ Bezpečnostní rizika pro ČR z pohledu veřejného mínění [online].

${ }^{106}$ CVVM: Dvě třetiny Čechů se zajímají o ochranu životního prostředí [online].

${ }^{107}$ HYNEK, Alois, SVOZIL, Břetislav, KARVÁNKOVÁ, Petra. Environmentální bezpečnost území ZnojmoRetz.

${ }^{108}$ CVVM: Dvě třetiny Čechů se zajímají o ochranu životního prostředí [online].

${ }^{109}$ FUKSA, Josef. Odpověd’ na zaslaný dotazník (V. Ú. V. TGM), 26. 3. 2008.

${ }^{110}$ MINISTESRTVO ŽIVOTNÍHO PROSTŘEDÍ ČR. Situační zpráva ke Strategii udržitelného rozvoje ČR, s. 91.

${ }^{111}$ Viz např́klad přehled novinových článků v textu Extrémní sucho - skutečná hrozba [online].

${ }^{112}$ BUZAN, Barry, WAEVER, Ole, DE WILDE, Jaap. Bezpečnost: nový rámec pro analýzu, s. 13.

${ }^{113}$ Ibid.

${ }^{114}$ Ibid., s. 240.

115 Ibid., s. 243.

116 ŠEBEK, Karel. Odpověd' na zaslaný dotazník (ODS), 5. 3. 2008.

\section{LITERATURA}

\section{Knižní zdroje a periodika}

[1] Bezpečnostní strategie České republiky. Praha: Ústav mezinárodních vztahů, 2003. 28 s. ISBN 8086345459. 
[2] BUZAN, Barry, WAEVER, Ole, DE WILDE, Jaap. Bezpečnost: nový rámec pro analýzu. Brno: Centrum strategických studií, 2005. 267 s. ISBN 8090333362.

[3] CÍLEK, Václav. Evropská žízeň. iHNed.cz [online], 8. 7. 2005. Dostupný z WWW: < http://ihned.cz/c4-10041240-16449060-000000_d-evropska-zizen >. ISSN 1213-7693.

[4] CÍLEK, Václav. Tsunami je stále s námi: eseje o klimatu, společnosti a katastrofách. Praha: Alfa Publishing, 2006. 343 s. ISBN 8086851222.

[5] Česká bezpečnostní terminologie: výklad základních pojmů. Editor Petr Zeman. Brno: Vojenská akademie v Brně - Ústav strategických studií, 2003. 186 s. ISBN 8021030372.

[6] HENDL, Jan. Kvalitativní výzkum: základní metody a aplikace. Praha: Portál, 2005. 407 s. ISBN 8073670402.

[7] HLADNÝ, Josef. a kol. Dopady možné změny klimatu na hydrologii a vodní zdroje v České republice. Praha: Český hydrometeorologický ústav, 1996. 137 s. ISSN 1210-7565.

[8] HYNEK, Alois, SVOZIL, Břetislav, KARVÁNKOVÁ, Petra. Environmentální bezpečnost území Znojmo-Retz. In DRESLEROVÁ, Jaromíra, GROHMANOVÁ, Lucie. Venkovská krajina 2007. Brno: Česká společnost pro krajinnou ekologii, 2007. s. 38-42. ISBN 8086386-88-0.

[9] KENDER, Jan. Voda v krajině. Praha: Consult, 2004. 207 s. ISBN 8090213278.

[10] KALVOVÁ, Jaroslava a kol. Scénáře změny klimatu na území České republiky a odhady dopadů klimatické změny na hydrologický režim, sektor zemědělství, sektor lesního hospodářství a na lidské zdraví v ČR. Praha: Český hydrometeorologický ústav, 2002. 141 s. ISBN 8086690016.

[11] KLAUS, Václav. Modrá, nikoli zelená planeta: co je ohrožen: klima, nebo svoboda?. Praha: Dokořán, 2009. 212 s. ISBN 9788073632434.

[12] KRÁSNÝ, Antonín, SOCHA, Oldřich. Možné vlivy bezpečnostního prostředí na Českou republiku a její ozbrojené síly. Obrana a strategie. 2006, roč. 6, č. 1, s. 7-18.

[13] MINISTERSTVO ŽIVOTNÍHO PROSTŘEDÍ ČR. Situační zpráva ke Strategii udržitelného rozvoje ČR. Praha: Ministerstvo životního prostředí, 2007. 164 s. ISBN 9788072124626.

[14] MOLLER, Bjorn. Fresh Water Sources, Security and Conflict: An Overview of Linkages. In RAVNBORG, Helle, BOESEN, Jannik. From Water 'Wars' to Water 'Riots' - Lessons from Transboundary Water Management. Copenhagen: Dansk Institute for Internationale Studier, 2004. s. 18-47. ISBN 87-7605-018-1.

[15] PETRŽÍLEK, Petr. Nedostatek vody a sucho - Opatření navrhovaná ČSSD $k$ zmírnění dopadi̊ klimatických změn. 2008. Nepublikováno.

[16] POSTEL, Sarah. Last Oasis - Facing Water Scarcity. New York: W.W. Norton \& Company, 1997. 239 s. ISBN 0393317447.

[17] PRETEL, Jan. Klimatická změna a její vlivy na vodní režim. Vodní hospodářství. 2006, č. 7, s. 2-7.

[18] RAUSITILIALA, Kal. States, NGOs, and International Environmental Institutions. International studies Quarterly. 1997, roč. 41, č. 4., s. 719-740.

[19] ROMANCOV, Michal. Voda: surovina strategičtější než ropa. Mezinárodní politika. 2004, roč. XXVIII, č. 7, s. 4-6.

[20] ̌ÍMAN, Martin. Příroda nepochybně přežije. My však ne. Mladá fronta Dnes, 23. 3. 2002.

[21] STERN, Nicolas. The economics of climate change: the Stern review. Cambridge: Cambridge University Press, 2007. 692 s. ISBN 9780521700801. 
[22] SYROVÁTKA, Oldřich, ŠíR, Miloslav, TESAŘ, Miroslav. Změna přístupů ke krajině podmínka udržitelného rozvoje. In PETŘÍČEK, Václav. Tvář krajiny - krajina domova. Lomnice nad Popelkou: Studio JB, 2001. 162 s. ISBN 8086512029.

[23] TOŠOVSKÁ, Eva. Environmentální bezpečnost. Mezinárodní politika. 2002, roč. XXVI, č. 3, s. 22-24.

\section{Internetové zdroje}

[24] Anotace úkolů 2006 [online], Výzkumný ústav vodohospodářský T. G. Masaryka, 2006. [cit. 2009-07-28]. Dostupný z < http://www.vuv.cz/Dokumenty/anotace/Anotace2006.pdf>.

[25] Bezpečnostní budoucnost České republiky. Otázky, výzvy a problémy [online], Středisko bezpečnostní politiky CESES, 2005. [cit. 2009-07-28]. 28 s. Dostupný z WWW: < http://www.ceses.cuni.cz/CESES-73-version1-sbornik_bb.pdf >.

[26] Bezpečnostní prognózy a realita [online], Středisko bezpečnostní politiky CESES, 2006. [cit. 2009-07-28]. $36 \quad$ s. Dostupný <http://publication.fsv.cuni.cz/attachments/146_012_Rasek.pdf >.

[27] Bezpečnostní rizika pro ČR z pohledu veřejného mínění [online], Centrum pro výzkum veřejného mínění, 2008. [cit. 2009-07-28]. 4 s. Dostupný z WWW: <www.cvvm.cas.cz/upl/zpravy/100753s_po80201.pdf >.

[28] CVVM: Dvě třetiny Čechů se zajímají o ochranu životního prostředí [online], Strana zelených, 2009. [cit. 2009-07-28]. Dostupný z WW: <http://www.zeleni.cz/5666/clanek/cvvm-dve-tretiny-cechu-se-zajimaji-o-ochranuzivotniho-prostredi $>$.

[29] Desertification - a threat to the Sahel [online], Eden Foundation, 1994. [cit. 2009-07-28]. Dostupný z WWW: < http://www.eden-foundation.org/project/desertif.html >.

[30] Dlouhodobý program - 6.3. Rozvoj zemědělství a venkova [online], Česká strana sociálně demokratická, 2007. [cit. 2009-07-28]. Dostupný z WWW: <http://www.cssd.cz/nasprogram/volebni-program/dlouhodoby-program-6-3.html >.

[31] Environmental Kuznets Curves: A Review of Findings, Methods, and Policy Implications [online], Property and Environment Research Cente, 2004. [cit. 2009-07-28]. 38 s. Dostupný z WWW: < http://www.perc.org/pdf/rs02_1a.pdf >.

[32] Environmentalismus - rozumná politika nebo další pokus o omezování osobní svobody?. [online], Internetové stránky M. Římana, 2000. [cit. 2009-07-28]. Dostupný z WWW: <http://www.riman.cz/articles2.php?user=\&pass=\&action=show\&ID=668>.

[33] Extrémní sucho - skutečná hrozba [online], Blog Petra Petržílka, 2008. [cit. 2009-07-28]. Dostupný z WWW: <http://petrzilek.blog.idnes.cz/c/29151/Extremni-sucho-skutecnahrozba.html>.

[34] Green Paper - Adapting to climate change in Europe - options for EU action [online], Evropská komise, 2007. [cit. 2009-07-28]. 27 s. Dostupný z WWW: <http://www.epha.org/IMG/pdf/Green_paper_on_climate_change.pdf >.

[35] HAMÁČKOVÁ, Eva. Evropa chce šetřit vodou, Česko budovat přehrady. Týden [online], 7. 8. 2009. [cit. 2009-11-28]. Dostupný z <http://wwww.tyden.cz/rubriky/domaci/evropa-chce-setrit-vodou-cesko-budovatprehrady_18621.html>. ISSN 1210-9940. 
[36] China says water pollution so severe that cities could lack safe supplies. ChinaDaily.com [online], 6. 7. 2005. Dostupný z WWW: <http://www.chinadaily.com.cn/english/doc/200506/07/content_449451.htm>. ISSN 0748-6154.

[37] Informační brožura o změně klimatu [online], Český hydrometeorologický ústav, 2003. [cit. 2009-07-28]. 59 s. Dostupný z WWW: < http://www.chmi.cz/cc/inf/klima.doc >.

[38] Jak ostrovní stát Malta získává pitnou vodu. Enviweb.cz [online], 19. 12. 2007. Dostupný z WWW:

<http://www.enviweb.cz/?secpart=voda_archiv_ghcjd/Jak_ostrovni_stat_Malta_ziskava_pit nou_vodu.html>. ISSN 1803-6686.

[39] Koncepce agrární politiky České republiky 2004 až 2013 [online], Ministerstvo zemédělství, 2003. [cit. 2009-07-28]. $57 \quad$ s. Dostupný z $\quad$ WWW: <http://81.0.228.70/attachments/PHP_schvaleny_vladou1.pdf >.

[40] MARTINOVSKÝ, Petr. Nedostatek vody. Sekuritaci.cz [online], 1. 11. 2008. [cit. 2009-0728]. Dostupný z WWW: <http://www.sekuritaci.cz/nedostatek-vody/cs/>. ISSN 1802-6710.

[41] Moderní ekologická politika KDU-ČSL [online], Křrest’anská a demokratická Unie - Čs. strana lidová, 2001. [cit. 2009-07-28]. Dostupný z WWW: <http://www.kdu.cz/default.asp?page=510\&idr=10150\&IDCl=14783>.

[42] MOLDAN, Bedřich. Není to horor, ale skutečnost. Virtually.cz [online], 22. 3. 2006. Dostupný z WWW: <http://www.virtually.cz/index.php?art=10797>. ISSN 1802-1522.

[43] MUNDIL, Stanislav. Topolánek se chce změnám klimatu věnovat dřív než socialisté. EkoList [online], 6. 3. 2007. [cit. 2009-07-28]. Dostupný z WWW: <http://ekolist.cz/zprava.shtml?x=1973456>. ISSN 1211-5436.

[44] Naděje pro Českou republiku - nevolební program KSČM [online], Komunistická strana Čech a Moravy, 2004. [cit. 2009-07-28]. Dostupný z WWW: <http://www.kscm.cz/index.asp?thema=2679\&category=>.

[45] Návštěvy volebního obvodu 2006 [online], Internetové stránky Petra Pitharta, 2006. [cit. 2009-07-28]. Dostupný z WWW: <http://www.pithart.cz/navstevy_vo_2006.pp>.

[46] Optimalizace krajinné struktury z hlediska hydrologických režimů [online], Výzkumný ústav meliorací a ochrany půdy, 2006. [cit. 2009-07-28]. Dostupný z WWW: <http://www.hydromeliorace.cz/VUMOP/projekty/npv164.htm>.

[47] Petr Gandalovič: Online rozhovor[online], Internetové stránky ODS, 2007 [cit. 2009-07-28]. Dostupný z WWW: <http://www.ods.cz/media/clanek.php?ID=5530>.

[48] Plán hlavních povodí České republiky [online], Ministerstvo zemědělství, 2007. [cit. 200907-28]. Dostupný z WWW: <http://81.0.228.70/attachments/PHP_schvaleny_vladou1.pdf >.

[49] Podzemní vody dramaticky ubývá, Právo, 10. 8. 2006.

[50] PRETEL, Jan. Změny klimatického systému [online], Stránky českého hydrometeorologického ústavu, 2007. [cit. 2009-11-28]. Dostupný z WWW: <http://www.chmi.cz/OS/metspol/prednasky/Pretel_klimaticka_zmena.pdf>.

[51] Přepis vystoupení B. Moldana v pořadu Otázky Václava Moravce [online], Internetové stránky Bedŕicha Moldana, 2007. [cit. 2009-07-28]. Dostupný z WWW: <http://www.moldan.cz/cze/stranka.php?ID=269>.

[52] Safe Drinking Water [online], United Nations Children's Fund, 2001 [cit. 2009-07-28]. Dostupný z WW: <http://www.unicef.org/specialsession/about/sgreportpdf/03_SafeDrinkingWater_D7341Insert_English.pdf $>$. 
[53] Stanovisko k Zelené knize „Adaptace na klimatickou změnu v Evropě - možnosti pro postup EU“ [online], Český hydrometeorologický ústav, 2007. [cit. 2009-07-28]. Dostupný z WWW: < http://www.chmu.cz/stanzelknihac.pdf >.

[54] STEJSKAL, Jan. Jan Pretel: Kjótský protokol nás zachránit žádným způsobem nemůže. EkoList [online], 17. 9. 2003. [cit. 2009-07-28]. Dostupný z WWW: <http://www.ekolist.cz/zprava.shtml?x=146537>. ISSN 1211-5436.

[55] Strategie udržitelného rozvoje České republiky [online], Ministerstvo životního prostředí, 2004. [cit. 2009-07-28]. 59 s. Dostupný z WWW: <http://www.env.cz/AIS/webpub.nsf/\$pid/MZPISF7Z6L7V/\$FILE/SUR\%20\%C4\%8CR_FINALlistopad2004.pdf>.

[56] Stručná historie Greenpeace [online], Greenpeace Česká republika, 2008. [cit. 2009-07-28]. Dostupný z WWW: < http://www.greenpeace.org/czech/about/historie >.

[57] Suburbanizace pražského okolí: dopady na sociální prostředí a krajinu [online], Vestecká zvonička, 2006. [cit. 2009-07-28]. Dostupný z WWW: < http://www.vesteckazvonicka.cz/files/active/0/Suburbanizace\%20pra\%C5\%BEsk\%C3\%A9 ho\%20okol\%C3\%AD..pdf >.

[58] Surovinová politika v oblasti nerostných surovin a jejich zdrojů [online], Ministerstvo průmyslu a obchodu, 2006. [cit. 2009-07-28]. 41 s. Dostupný z WWW: <download.mpo.cz/get/26649/32420/345278/priloha002.doc >.

[59] Třetí předvolební zpravodaj KDU-ČSL [online], Křest’anská a demokratická Unie - Čs. strana lidová - místní organizace v Mostech u Jabli̊nkova, 2006. [cit. 2009-07-28]. Dostupný z WWW: <ceskytesin.kdu.cz/text/mo/mostyujablunkova/VP2006-2010_3.doc >.

[60] Vodovody a kanalizace 2006 [online], Ministerstvo zemédělství, 2007. [cit. 2009-07-28]. Dostupný z WWW: 〈http://81.0.228.70/attachments/VaK_2006.pdf >.

[61] Volební program pro volby do Poslanecké sněmovny z roku 2006 [online], Komunistická strana Čech a Moravy, 2006. [cit. 2009-07-28]. Dostupný z WWW: $<$ http://www.kscm.cz/article.asp?thema=3783\&category=>.

[62] Volební program Strany zelených „Kvalita života“ pro volby do Poslanecké sněmovny 2006 [online], Strana zelených, 2006. [cit. 2009-07-28]. Dostupný z WWW: <http://www.zeleni.cz/59/rubrika/volebni-program/>.

[63] Water and Conflict [online], Dansk Institute for Internationale Studier, 2004. [cit. 2009-0728]. 100 s. Dostupný <http://www.diis.dk/graphics/Publications/Reports2004/hmr_waterconflict.pdf >.

[64] Water Conflict Chronology [online], Pacific Institute: The World's Water, 2008. [cit. 200907-28]. 46 s. Dostupný z WWW: <http://www.worldwater.org/conflictchronology.html >.

[65] World Resources 2005 [online], United Nations Development Programme, 2005. [cit. 200907-28]. 246 s. Dostupný z WWW: < http://pdf.wri.org/wrr05_full_hires.pdf >.

[66] World Water Resources and Regional Vulnerability: Impact of Future Changes [online], International Institute for Applied Systems Analysis, 1993. [cit. 2009-07-28]. 138 s. Dostupný z WWW: < http://www.iiasa.ac.at/Admin/PUB/Documents/RR-93-010.pdf >.

[67] Zpráva o stavu vodního hospodářství 2006 [online], Ministerstvo zemédělství, 2007. [cit. 2009-07-28]. Dostupný z WWW: <http://81.0.228.70/attachments/Modra_zprava_2006.pdf $>$.

[68] Zpřesnění dosavadních odhadů dopadů klimatické změny v sektorech vodního hospodářství, zemědělství a lesnictví a návrhy adaptačních opatření [online], Informační systém výzkumu a vývoje, 2007. [cit. 2009-07-28]. Dostupný z WW: <http://aplikace.isvav.cvut.cz/projectDetail.do?rowId=SP\%2F1A6\%2F108\%2F07>. 


\section{Použité dotazníky}

[69] BARTOŠOVÁ, Markéta. Odpověd’ na zaslaný dotazník (Arnika), 11. 3. 2008.

[70] BLAŽEK, Tomáš. Odpověd' na zaslaný dotazník (Sdružení Krajina), 5. 3. 2008.

[71] FUKSA, Josef. Odpověd' na zaslaný dotazník (V. Ú. V. TGM), 26. 3. 2008.

[72] KOTECKÝ, Vojtěch. Odpověd' na zaslaný dotazník (Hnutí Duha), 28. 3. 2008.

[73] PETRŽíLEK, Petr. Odpověd’ na zaslaný dotazník (ČSSD), 27. 3. 2008.

[74] ̌ÍHA, Martin. Odpověd' na zaslaný dotazník (Společnost pro trvale udržitelný život), 5. 3. 2008.

[75] SLAVOTÍNEK, Rostislav. Odpověd’ na zaslaný dotazník (KDÚ-ČSL), 5. 3. 2008.

[76] SRNCOVÁ, Jitka. Odpověd’ na zaslaný dotazník (Sdružení Jihočeské matky), 5. 3. 2008.

[77] ŠEBEK, Karel. Odpověd’ na zaslaný dotazník (ODS), 5. 3. 2008.

[78] ŠUCHMANOVÁ, Eva. Odpověd’ na zaslaný dotazník (Pražské matky), 5. 3. 2008. 